\title{
Hradisko Tabulová hora u Klentnice v době popelnicových polí
}

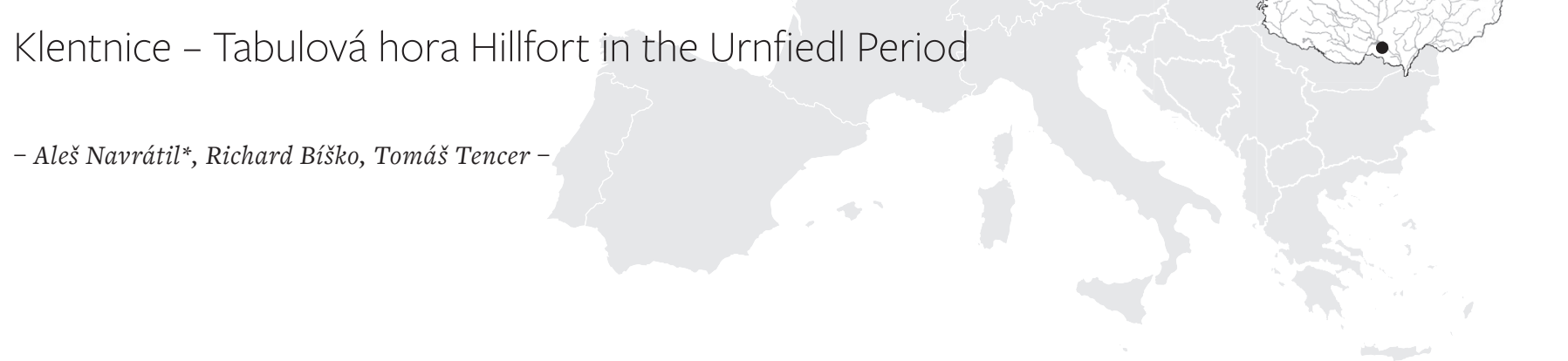

\section{KEYWORDS:}

The South Moravia Region - Klentnice - hillfort - Urnfield period earthwork - LIDAR - geomagnetic survey - metal detecting looting - survey - Urnfield society

\section{ABSTRACT}

Tabulová hora hillfort plays a prominent role in the landscape of the South Moravia region. The excavation in 50's brought basic information about the wall construction. At the beginning of the 21st century rumours about illegal metal detecting activities started to spread. According to this rumours a significant number of Bronze Age hoards as well as exclusive items were illegally excavated. This sparked a new wave of professional interest leading to a series of archaeological non-destructive activities on the site. The aim of this study is to present new results of defence system survey as well as geomagnetic survey of particular hillfort sections. The results are confronted with the data coming from the past excavations. A discussion on the role of hillforts in the Urnfield society follows.
* Corresponding author - E-mail address: navratil@spilberk.cz

\section{Úvod}

Archeologické nálezy z doby bronzové $\mathrm{v}$ katastru obce Klentnice patří k nejstarším moravským památkám, které byly popsány v odborné literatuře (Klemm 1836, 440-442). Díky nim vznikla také jedna z nejstarších archeologických sbírek na Moravě. Na počátku byl enormní počet náhodných objevů bronzových a keramických artefaktů nalézaných na východním úpatí Tabulové hory v prostoru dnešní obce Klentnice, a to již počátkem 19. století. Profesionální archeologickou pozornost přitáhla lokalita až v 50. letech 20. století ( ̌́íhovský 1955; 1965a). V roce 1958 byla Tabulová hora vyhlášena kulturní památkou.

Po roce 2000 došlo na Pavlovských vrších k nové vlně početných a tentokráte nikoliv náhodných nálezů. Dělo se tak však zcela mimo archeologické struktury a legální rámec. Dnes se pouze zpětně a jen s minimální možností ověření dostáváme k informacím o rozsáhlých aktivitách rabovačů archeologických lokalit s detektory kovů (Navrátil 2010; Vích 2009, 142).

Nedostatečná probádanost, pouze informativní prezentace výsledků výzkumů z 50. let a skutečnost, že dnes je již většina kovového nálezového potenciálu Tabulové hory rozchvácena, jsou smutnými fakty zejména v kontextu oprávněné domněnky, že tato lokalita patřila $\mathrm{v}$ době popelnicových polí $\mathrm{k}$ významným společensko-ekonomickým centrům nadregionálního významu.

$S$ vědomím této neutěšené situace zorganizovalo Regionální muzeum v Mikulově ve spolupráci s Muzeem města Brna mezi lety 2008 až 2019 téměř dvě desítky jednodenních prospekcí, do nichž byli zapojeni spolupracující uživatelé detektorů kovů. Cílem akcí bylo ověřit míru narušení lokality a zároveň získat nové informace, které by doplnily badatelský obraz Tabulové hory a jejího širšího zázemí.

Již v průběhu prvních prospekcí na Tabulové hoře a v okolí bylo zřejmé, že zaměření opevnění z roku 1988 (Dohnal 1988) je tř̌eba aktualizovat. $V$ roce 2013 proto bylo na lokalitě provedeno zaměření reliktů ohrazení a terénních hran pomocí ručního submetrického GPS zařízení. Dalším výrazným příspěvkem k identifikaci reliktů bylo získání dat leteckého laserového skenování. V roce 2020 pak bylo provedeno magnetometrické měření akropole a části 1. předhradí zaměstnanci Ústavu archeologie a muzeologie FF MU.

Tato studie si klade za cíl prezentaci výsledků nového zamèření reliktů opevnění a výsledků měření dostupných ploch magnetometrem. Součástí studie je také úvaha o roli hradiště ve společnosti popelnicových polí. Výsledky detektorové prospekce z let 2008-2019 včetně podrobného chronologického vyhodnocení nových i starších nálezů z Tabulové hory a okolních lokalit přesahují možnosti tohoto článku, a budou proto součástí jiné studie. 


\section{Geografický kontext lokality}

Hradisko Tabulová hora se nachází na nejjižnějším ze tři hlavních Pavlovských vrchů. Pavlovské vrchy, nebo také Pálava, je vápencový masiv na rozhraní Dyjsko-svrateckého a Dolnomoravského úvalu. Jeho tř̌i nejvyšší vrcholy - Stolová hora (k. ú. Klentnice), Kotel (k. ú. Perná) a Děvín (k. ú. Pavlov) - jsou situovány vedle sebe v přibližné ose sever-jih (obr. 1), převyšují okolní nížinu až o 360 m a vytvářejí tak dominantu širokému

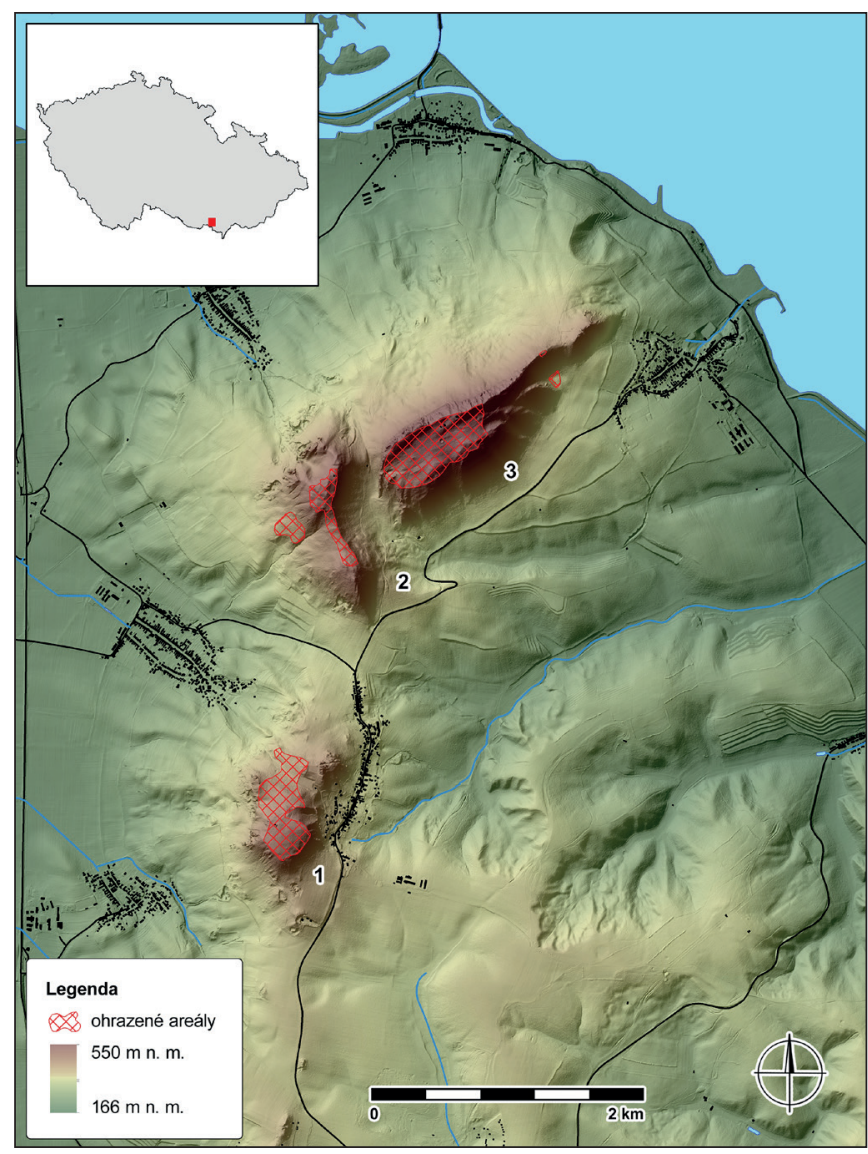

Obr. 1. Pavlovské vrchy s vyznačenými opevněnými areály. 1 - Klentnice - Tabulová hora; 2 - Perná - Kotel; 3 - Pavlov - Děvín. Autor R. Bíško.

Fig. 1. Pavlov Hills with walled sites. 1 - Klentnice - Tabulová hora; 2 - Perná - Kotel; 3 - Pavlov - Děvín. Author R. Bíško.

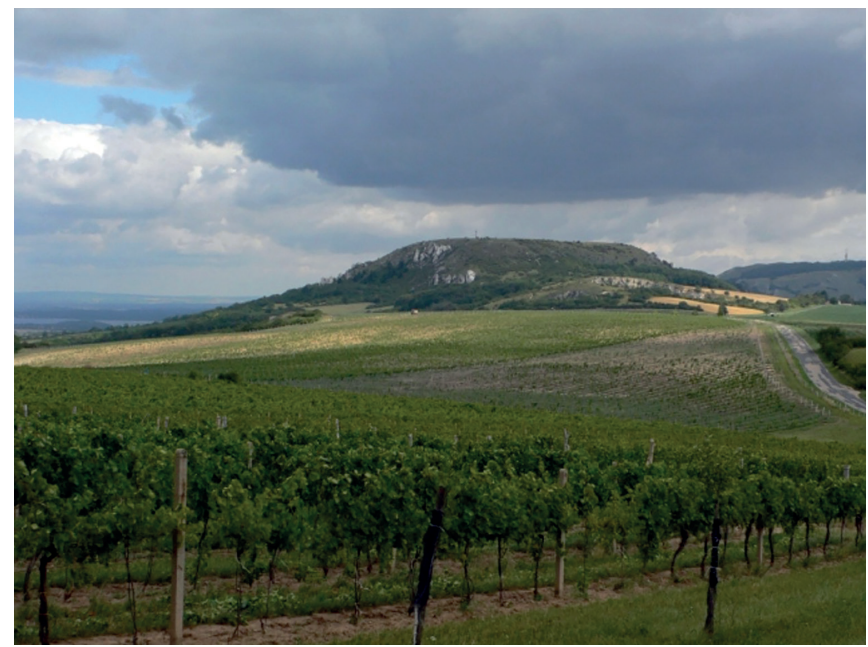

Obr. 2. Stolová hora od jihu. V pozadí Děvín. Foto R. Bíško.

Fig. 2. Stolová hora from south with Děvín hill at the background. Photo by R. Bíško. okolí (obr. 2). Zároveň jejich umístění nad soutokem tří větších moravských řek (Dyje, Svratka, Jihlava), a tedy na křižovatce komunikačních koridorů, činilo z Pálavy klíčový strategický i symbolický prvek v pravěké sociální krajině (obr. 3).

Název „Tabulová hora“ vychází ze staršího německojazyčného názvu „Tafelberg“. Tento název zakořenil v archeologické literatuře (Čižmář 2004, 144), ačkoliv na současných mapách i v každodenní praxi bývá lokalita mnohem častěji označována jako „Stolová hora“. Nejvyšší bod lokality sahá do výšky 458,5 m nad mořem. V textu se proto pojmem „Tabulová hora“ obracíme k archeologické lokalitě, zatímco termín „Stolová hora“ chápeme jako geografický prvek. Na rozdíl od morfologicky výraznějšího Děvína a Kotle tvoří Stolová hora nápadné plató o rozloze 7,2 ha, které je lemováno prudkými svahy či přímo skalními útesy s př̀evýšením téměř $40 \mathrm{~m}$. Vizuálně je z lokality možné kontrolovat oblast nivy Dyje a soutoku řek na vzdálenost několika kilometrů.

\section{Dějiny archeologického bádání na katastru Klentnice}

Nebývalá frekvence náhodně nalézaných pravěkých předmětů na katastru obce Klentnice přitahovala pozornost zájemců o prehistorii nejpozději od počátku 19. století. Důvodem je lokalizace zahrad a polností obce Klentnice v prostoru rozsáhlé zaniklé aglomerace $\mathrm{z}$ doby bronzové. Její součástí byly nejen samotné hradiště Tabulová hora a jeho svahy, ale také nejbližší satelitní sídliště a pohřebiště.

Nejstarší publikovaná zmínka o pravěkých nálezech z Klentnice pochází z roku 1836 z pera archiváře dietrichsteinského zámku v Mikulově K. Wenzelida, který zveřejnil krátkou stat o moravských starožitnostech v knize německého historika Gustava Klemma (Klemm 1836, 440-442). Jedná se tak o jednu z nejstarších publikací týkajících se moravských archeologických památek vůbec. Zde Wenzelides vzpomíná na události z roku 1817, kdy mu klentnický farář přinesl bronzové předměty a pravěké keramické nádoby objevené místními obyvateli v okolí klentnického hřbitova. Wenzelides nálezy uložil v zámecké knihovně v Mikulově a založil tak jednu z nestarších moravských sbírek. V průběhu 19. století se Klentnice dostala do archeologické literatury ještě několikrát (Koch 1853, 27; Liedermann 1873, 137-138).

Stále rostoucí četnost náhodných nálezů dala v roce 1923 vzniknout malému muzeu s názvem „Südmärisches Heimatmuseum Klentnitz “přímo v Klentnici (Kirsch 2008, 99, 258). Sbírky ze zámecké knihovny (která byla jako jediná část zámku ušetřena požáru v roce 1945) i klentnického muzea byly v roce 1945 z velké části rozchváceny a jejich zbytky následně převedeny do sbírek obecního muzea v Mikulově (dnes Regionální muzeum v Mikulově).

Počátkem 50. let se archeologii Pavlovských vrchů začal systematicky věnovat badatel Státního archeologického ústavu Jiří Ríhovský. První akcí, která stála na počátku dalšího archeologického bádání, byl náhodný nález bronzového depotu v roce 1950. Byl nalezen při budování fotbalového hřiště v sedle mezi Stolovou horou a Sirotčím hrádkem (Ř́hovský 1950; Salaš 2005, 427-431). Dva roky po objevu depotu zahájil Ř́hovský sondážní výzkum na Stolové hoře v místě předpokládané brány ve valovém opevnění (obr. 4, 6; Říhovský 1955). Ve stejném roce mělo dojít k rozšíř̌ení drůbežárny na severním konci Klentnice v prostoru, kde již v té době byla známa existence žárového pohřebiště. Proto se přistoupilo k předstihovému záchrannému výzkumu, jehož vedením byla pověřena J. Páleníková (1953). Výzkum pohřebiště proběhl během tř́i sezón v letech 1955-1957 (Říhovský 1956; 1965a; 1970). V roce 1958 se Říhovský vrátil na Stolovou horu, kde položil dlouhou pásovou sondu od jižního okraje do středu hradiště (obr. 6; Ř́íhovský 1958). 


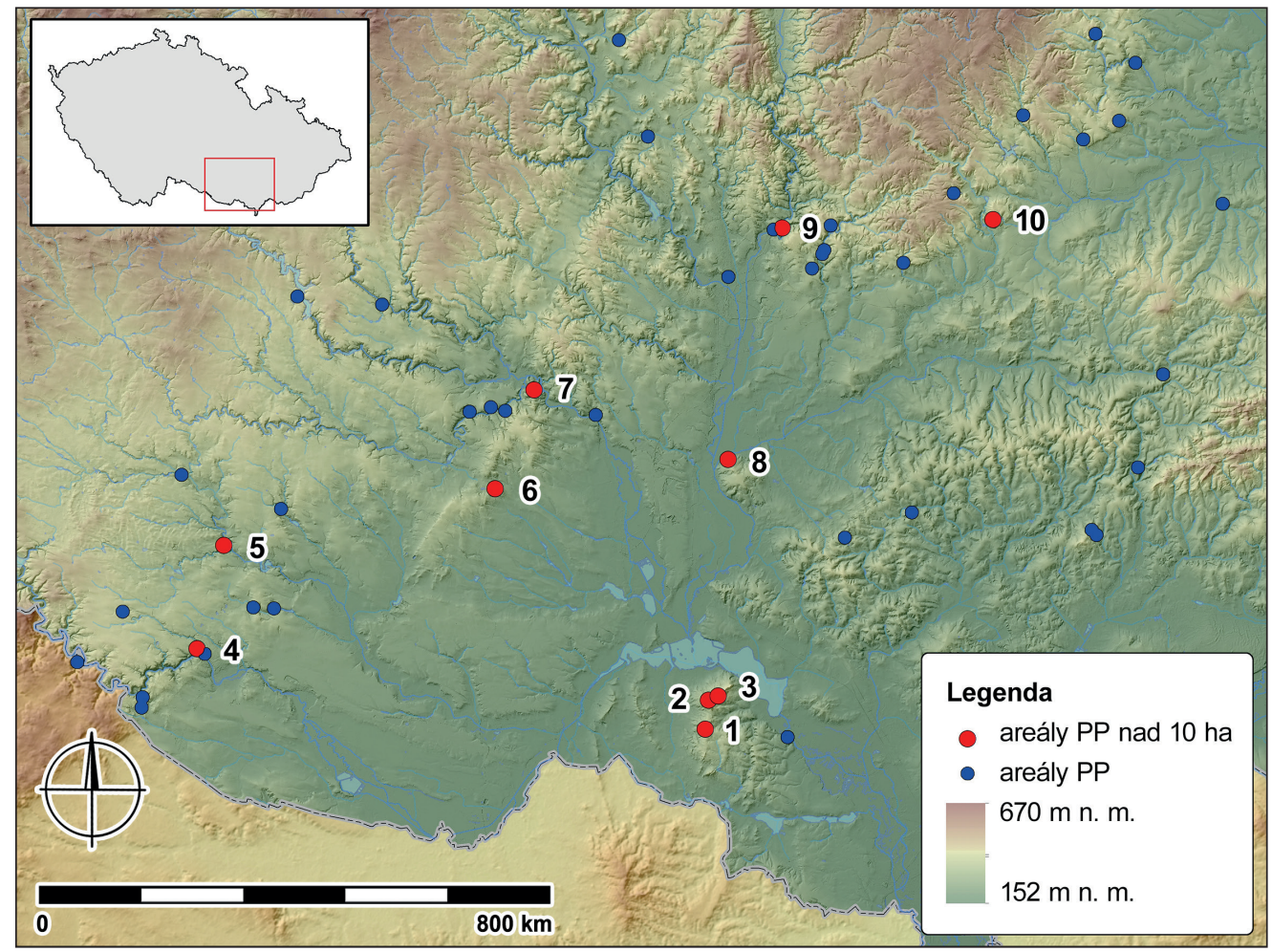

Obr. 3. Reliéfní mapa jižní Moravy s vyznačenými hradisky doby popelnicových polí. 1 - Klentnice Tabulová hora; 2 - Perná - Kotel; 3 - Pavlov - Děvín; 4 - Znojmo Hradiště; 5 - Plaveč - Šance; 6 - Olbramovice - Leskoun; 7 - Ivančnice - Réna; 8 - Blučina Cezavy; 9 - Obřany - Hradisko; 10 - Luleč - Sv. Martin. Autor R. Bíško. Fig. 3. Relief map of the South Moravia region with marked Urnfield period hillforts. Red dots mark sites over 10 ha. 1 - Klentnice - Tabulová hora; 2 - Perná - Kotel; 3 - Pavlov - Děvín; 4-Znojmo - Hradiště; 5 - Plaveč Šance; 6 - Olbramovice - Leskoun; 7-Ivančnice - Réna; 8 - Blučina Cezavy; 9 - Obřany - Hradisko; 10-Luleč - Sv. Martin. Author R. Bíško.

Souborného publikování se dočkala větší část hrobů z klentnického pohřebiště (Ř́hovský 1965a; 1970), nálezy z výzkumů na Stolové hoře zůstaly až na některé jednotlivé předměty nepublikovány. Situace zjištěná při výzkumu valu a brány v roce 1952 byla popsána pouze v krátkém informativním článku v Archeologických rozhledech (Říhovský 1955).

\section{Relikty opevnění Tabulové hory}

Podrobnější zmapování pozůstatků valů na Stolové hoře publikoval Vít Dohnal (1988). V tomto plánu, stejně jako ve všech dosavadních studiích týkajících se Tabulové hory, bylo jako lokalita hradiska chápáno náhorní plató Stolové hory o rozloze 7,2 ha

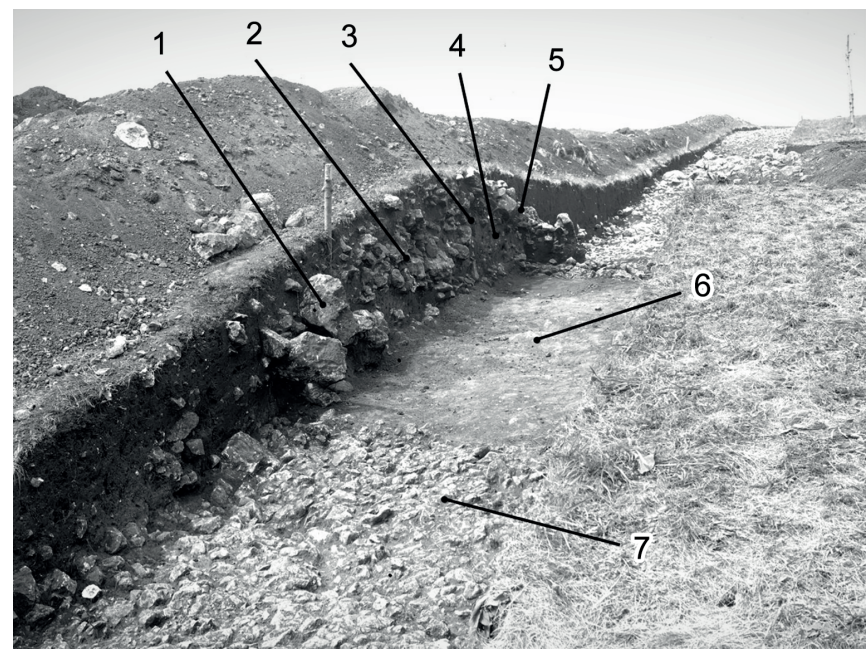

Obr. 4. Fotografie řezu valem z výzkumu J. Říhovského v roce 1952. 1 - možný pozůstatek kamenné plenty; 2 - těleso valu; 3 - možný pozůstatek zadní plenty; 4 - těleso rampy; 5 - povrchová úprava rampy; 6 - základna valu; 7 - skalní podloží. Uloženo varchivu Archeologického ústavu AV ČR, Brno.

Fig. 4. Picture of wall excavation conducted by J. Říhovský in 1952. 1 - possible remains of stone facing; 2 - wall fill; 3 - possleble remains of rear facing; 4-ramp fill; 5 - ramp surface; 6 - base of the wall; 7 - rock. Archived in the Institue of Archaeology of the Czech Academy of Sciences, Brno.
(Čižmář 2004, 144). Během opakovaných prospekcí lokality a okolí však vyšlo najevo, že hradisko ve skutečnosti sestává ze trrí samostatných valem ohrazených částí o celkové rozloze téměř 24 ha, z nichž náhorní plató je pouze jednou z nich. V dalším textu budeme náhorní plošinu nadále označovat jako akropoli. K té je na severní straně svahem připojena plocha, kterou označujeme jako 1. předhradí. Plocha je ohraničena na severní straně výraznou terénní hranou s převýšením až $4 \mathrm{~m}$ nad výraznou bermu. Jako 2. předhradí můžeme pojmenovat plochu označovanou ve starších nálezových zprávách jako „sedlo mezi Tabulovou horou a Růžovým hradem“. Poloha je na severní straně ohraničena dlouhou a výraznou terénní hranou místy přecházející ve zřetelný val (obr. 5, 6). Všechny tř̌i plochy s dobře patrným ohraničením zachytil v 90. letech na leteckém snímku Miroslav Bálek (obr. 7). V roce 2013 byly všechny doposud zjištěné relikty nově geodeticky zaměřeny.

Vizuální průzkum reliktů fortifikací probíhal podle standardích metod povrchové prospekce antropogenních reliéfních tvarů (metodika např. Kuna, Tomášek 2004). Vlastní zaměření bylo provedeno za pomoci př́stroje Trimble GeoXH 6000 metodou GPS v bezvegetačním období na jaře 2013. Důraz byl kladen na detekci hran antropogenních reliktů (tedy koruny valů, př́ípadně bermy). Podrobnější geodetické měření vzhledem k dostupnosti podrobných výškopisných informací nebylo realizováno. Informace z dat leteckého laserového skenování pochází z měření ČUZK a jde o tzv. surová data po robustní filtraci (více o možnostech využití v archeologii např. Gojda, John eds. 2013).

\section{Akropole}

Akropole Tabulové hory je tvořena náhorním plató nepravidelného půdorysu, které je ze západní a jihozápadní strany lemováno skalními útesy, z jižní a východní strany př́íkrými svahy. Je obehnána pozůstatky valového opevnění (v délce cca 900 m), které je velmi nezřetelné. Destrukce je velmi špatně viditelná na JV a V straně, kde se místy dochovala i typická prohlubeň na vnitřní straně destrukce. Na J a Z straně má dochování podobu pouze několik metrů široké plošiny. V nejzřretelnějších úsecích 
Obr. 5. Tabulová hora - snímek vytvořený z dat kolmého laserového snímkování. Podkladová data Český úřad zeměměřický a katastrální. Autor R. Bíško.

Fig. 5. Tabulová hora - a picture based on LIDAR data. Background data by State Administration of Land Surveying and Cadastre.

Author R. Bísko.

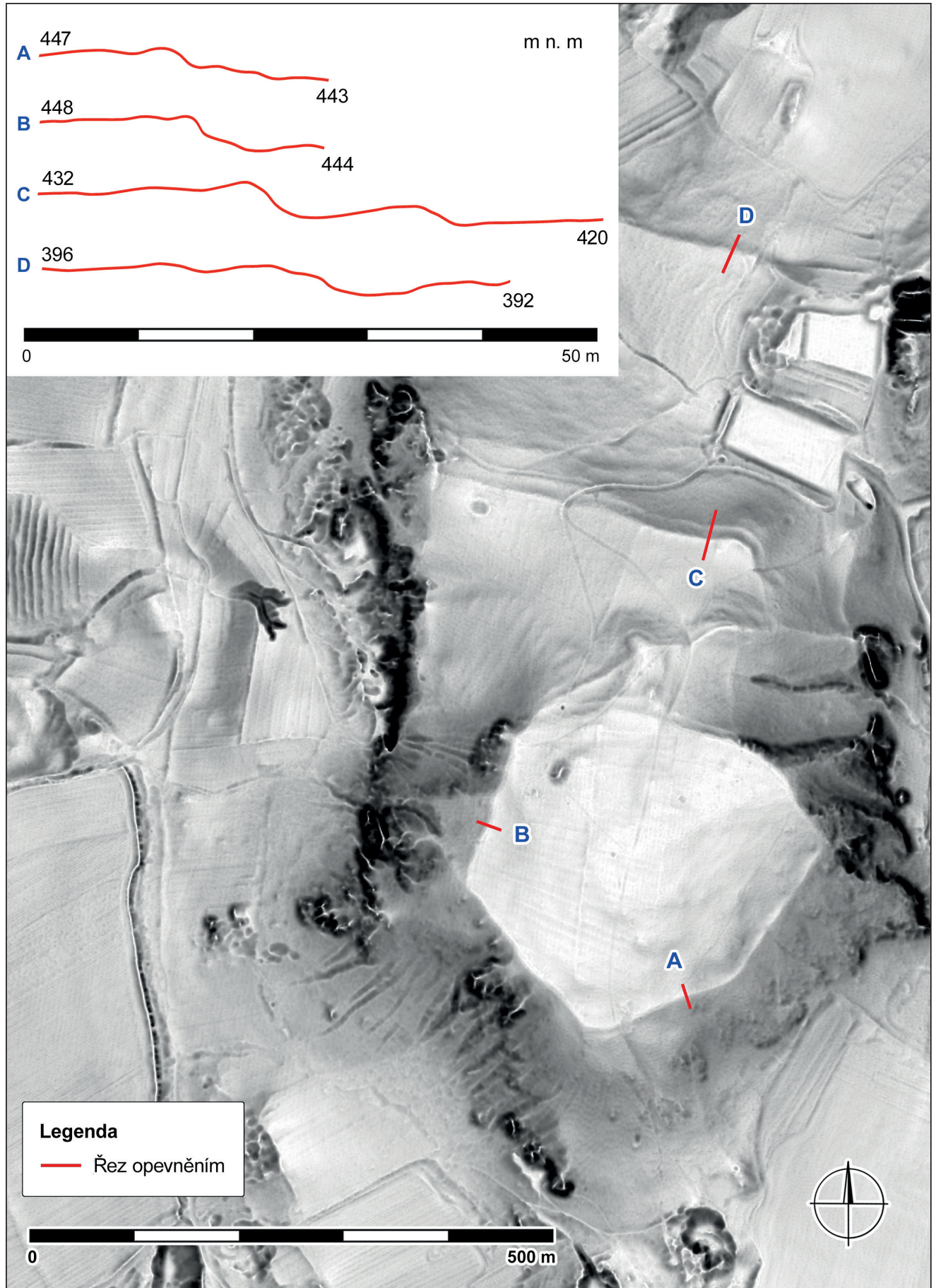

na SV se převýšení pohybuje okolo $0,3 \mathrm{~m}$. Severní část přechází šíjovým útvarem do prvního předhradí a vzhledem k četným geomorfologickým anomáliím je zde situace dosti nejasná.

Pouze na základě analýzy dat leteckého laserového skenování lze identifikovat náznaky destrukce hradby, která pokračuje z vrcholové plošiny SV směrem ke dvojici skalních výchozů a vytváří tak možný náznak jakéhosi vstupního systému. Tento prostor označil na základě letecké fotografie jako vstup také J. Peška (1997). Vlastní severní okraj vrcholové plošiny je ohrazen nejen neznatelnou destrukcí hradby, ale také menší plošinou, pravděpodobně bermou.

Zajímavý je výběžek nacházející se v prostoru předpokládané brány. Má oválný tvar a zasahuje několika metry do prvního předhradí. Připomíná novověký bastion, ačkoliv je pravděpodobné, že reliéfní tvar byl pouze nepatrně upraven.
Vlastní akropole dále rozčleněná není. Z dat leteckého laserového skenování je možné rozpoznat pravidelné parcelování celé západní části vrcholové plošiny. S nejvyšší pravděpodobností jde o původní polní parcelaci ze subrecentní doby, kdy byla plošina Stolové hory zemědělsky využívaná.

\section{1. předhradí}

Této nápadné plochy si již dříve povšiml J. Říhovský a zanesl ji do svého informativního plánku jako přidruženou plochu k samostatné akropoli (Ř́́hovský 1957, obr. 60). V žádném ze svých textů se však o ní nezmínil. V. Dohnal tuto plochu opomenul zcela. První předhradí je situováno cca $80 \mathrm{~m}$ severně od akropole a bylo opevněno pouze ze strany severní, kde je možné identifkovat dobře čitelné pozůstatky destrukce hradby (vysoké cca $4 \mathrm{~m}$, v délce $370 \mathrm{~m}$ ) a také přibližně $6 \mathrm{~m}$ 


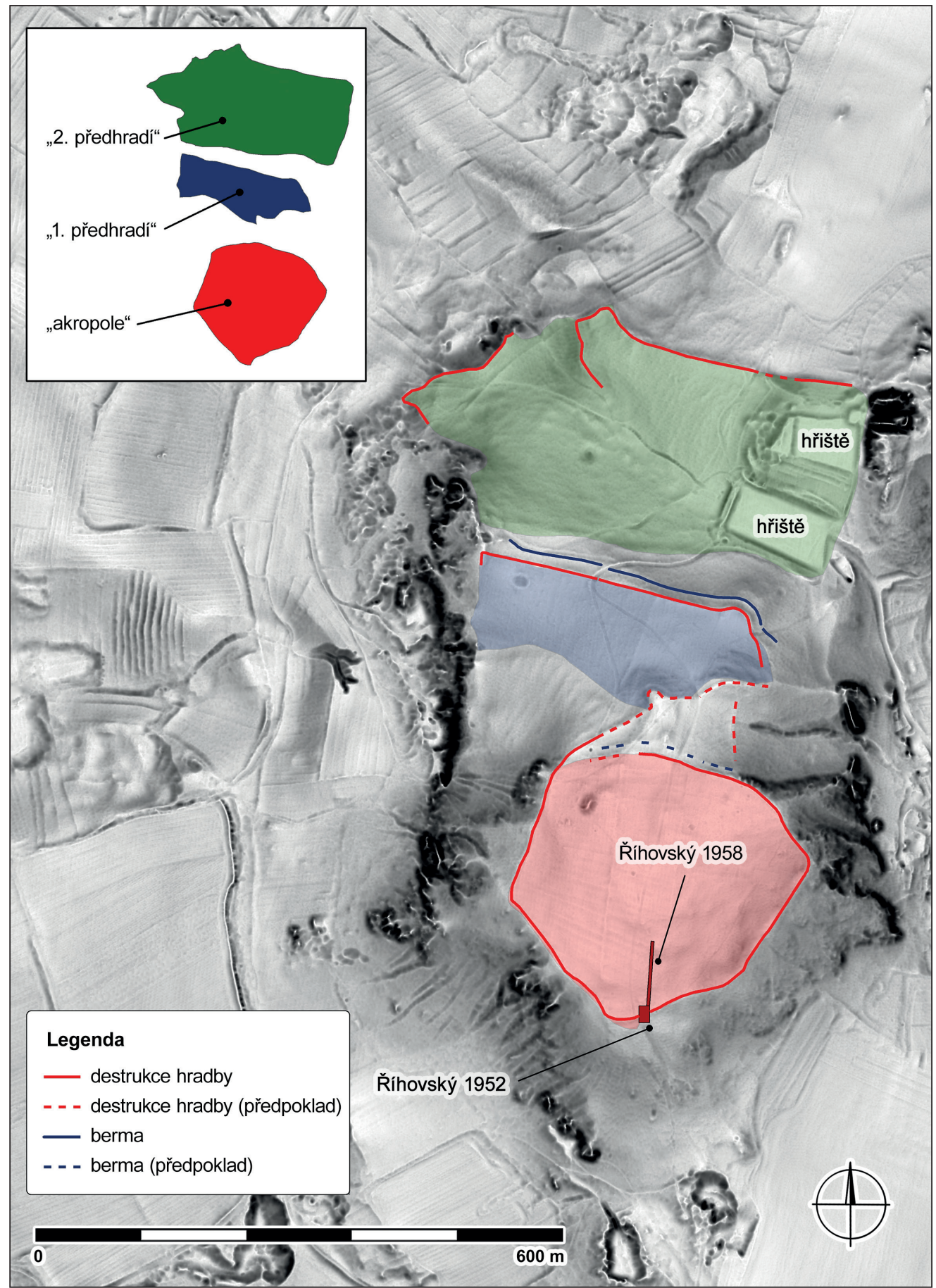

Obr. 6. Tabulová hora - snímek vytvořený z dat kolmého laserového snímkování s vyznačením zaměřeného opevnění. Černým rámečkem jsou vyznačeny výzkumy J. Říhovského z let 1952 a 1958. Podkladová data Český úřad zeměměřický a katastrální. Autor R. Bíško.

Fig. 6. Tabulová hora - a picture based on LIDAR data with marked results of defence system survey. Black frames mark the excavations from 1952 and 1958. Background data by State Administration of Land Surveying and Cadastre. Author R. Bíško.

širokou bermu zakončenou prudkým svahem, který spadá až do prostoru 2. předhradí.

Podobně jako v př́ípadě šíjového výběžku mezi akropolí a 1. předhradím lze v opevnění identifikovat výrazný půlkruhovitý výběžek o šířce přibližně $10 \mathrm{~m}$. Mohlo by se teoreticky jednat o uměle vytvořený relikt, obdoba novověkého bastionu chránícího potencionální vstup do hradiska. Celá plocha 1. předhradí se mírně svažuje západním směrem, kde je ohraničena skalními útesy s převýšením až $40 \mathrm{~m}$.

\section{2. předhradí}

Druhé předhradí se nachází v sedle mezi svahy Stolové hory a skalním bradlem Sirotčího hrádku. Tato lokalita byla J. Říhovským vždy chápána jako samostatné satelitní sídliště. Teprve v průběhu detektorových prospekcí vyšlo najevo, že jde o další plochu ohrazenou ze severní strany výrazným valem. Z lokality pochází celá řada náhodných archeologických nálezů souvisejících mimo jiné s budováním dvou hřišt v letech 1949 a 1950 (obr. 6). Během planýrování plochy hřišt', kdy byly buldozerem odstraněny téměř $2 \mathrm{~m}$ terénu, došlo $\mathrm{k}$ nálezu již zmíněného bronzového depotu. Na místo byl tehdy přivolán J. Ř́hovský. Ten už jen mohl konstatovat narušení archeologických situací, které se ve zbytcích rýsovaly na odtěžených profilech (Říhovský 1950, 1955). Jako zajímavost je třeba zmínit svědectví J. Liedermanna $\mathrm{z}$ počátku 70. let 19. století, podle kterého se v místě pod Sirotčím hradem (tedy v místě současné planýrky) nacházela menší mohyla nazývaná místními obyvateli „Goldhügel“ (Liedermann 1873, 137).

Samotné opevnění se opírá o okraj předhradí Sirotčího hrádku a pokračuje přibližně $250 \mathrm{~m}$ západním směrem do prostoru dalších skalních výchozů. Zde byla opět využita geomorfologie 
Obr. 7. Letecká fotografie Stolové hory od severu. Foto M. Bálek.

Uloženo varchivu Ústavu

archeologické památkové péče Brno. Upravil A. Navrátil.

Fig. 7. Aerial photo of Stolová hora from north with marked visible earthworks of indivituall hillfort parts. Photo by M. Bálek. Archived in Institut for Archaeological Heritage Brno. Adjusted by A. Navrátil.
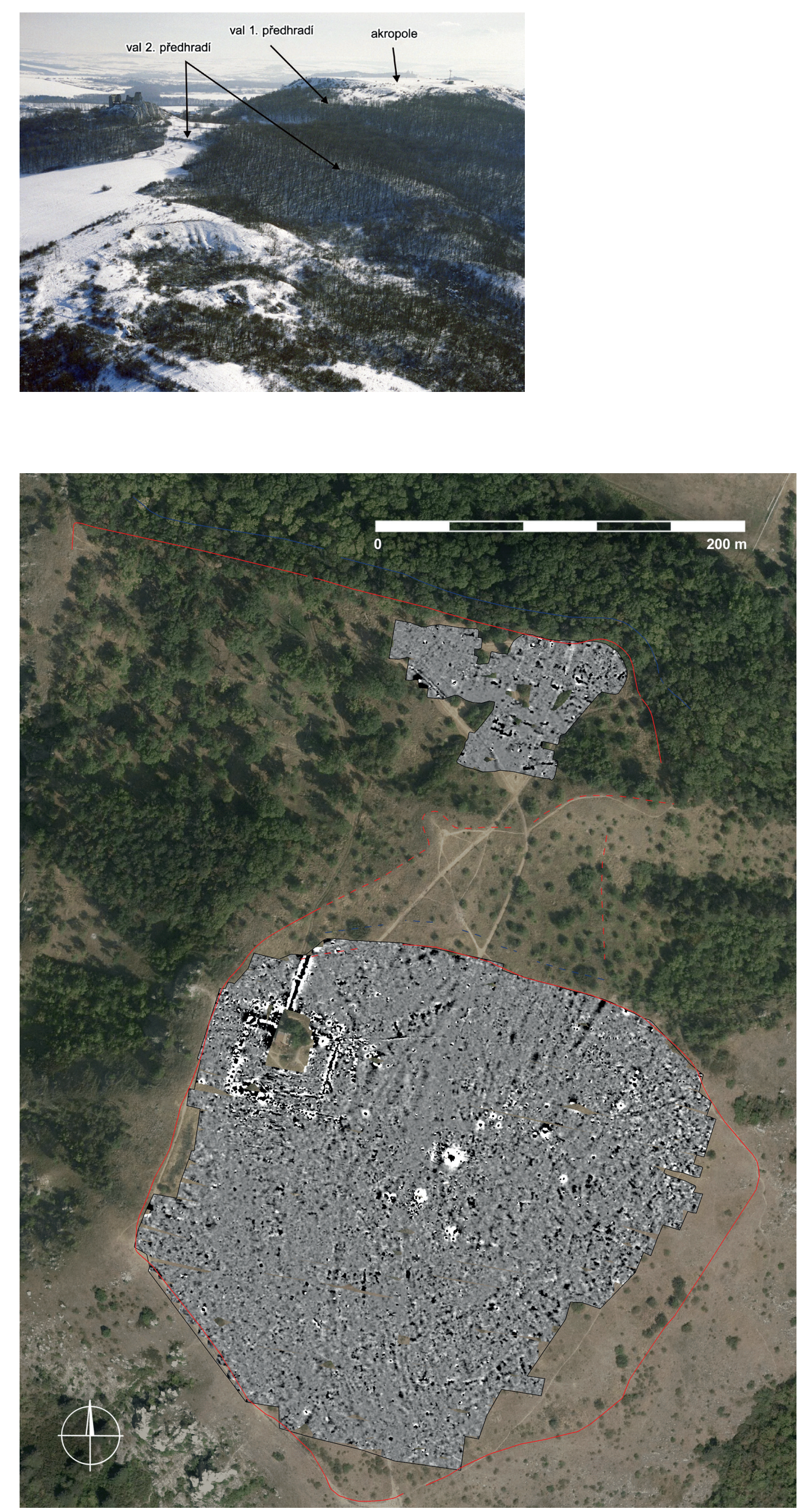

Obr. 8. Magnetogram zkoumané plochy - hodnoty zobrazeny v šede škále pozitivní (černá); negativn (bila): rozsah hodnot $15 /$ Podkladová data Český úřad zeměměřický a katastrální. Autor T. Tencer.

Fig. 8. Results of geomagnetic survey. Dynamics of color range adjusted. Value range is 15/-15 NT. Background data by State Administration of Land Surveying and Cadastre.

Author $T$. Tencer. 
terénu, opevnění se stáčí do oblouku směrem na JV, kde postupně doznívá. Destrukce má podobu asi 2 m vysoké terénní hrany, ve východní části lze identifikovat několik desítek centimetrů hlubokou prohlubeň. Podobně jako na 1. přehradí, na V i Z svah přechází do úžlabin svahujících se do údolí.

V kontextu ostatních hradisek doby popelnicových polí je opevnění a struktura Tabulové hory v oblasti jižní Moravy ojedinělá. U většiny opevněných areálů z tohoto období se nepředpokládá členění na akropoli a předhradí. $V$ tomto měřítku by sem bylo možné zařadit „Hradisko“ Obřany, př́ípadně Plaveč „Šance“. V př́ípadě hradiska u Plavče a opevnění jeho „akropole“ se ovšem někdy uvažuje o vzniku až v době halštatské (Nekvasil 1991, 461-462). Terénní vlna rozdělující opevněný areál je viditelná v př́ípadě lokality Javorník „Hradisko“, ale zde je zase zařazení do období popelnicových polí na základě absence průkazného materiálu značně problematické (Dohnal 1988, 22).

\section{Geomagnetický průzkum}

Průzkum na poloze Stolová hora v katastru obce Klentnice byl realizován fluxgate magnetometrem LEA MAX (Eastern Atlas, Německo). Př́istroj je konstruovaný jako gradiometr. Vzhledem ke komplikovanému terénu byl použit manuální mód (př́ístroj byl tlačen na vozíku ručně). Pro měření bylo použito 10 fluxgate sond (FEREX CON 650, Foerster, Německo) nakonfigurovaných ve vzdálenosti $0,5 \mathrm{~m}$ od sebe. Hustota geomagnetických měření byla $0,5 \mathrm{~m}$ na ose $\mathrm{X}$ a $0,1 \mathrm{~m}$ na ose $\mathrm{Y}$ (směr měření). Naměřená data jsou zapsaná současně s prostorovou informací z GNSS přijímače - Trimble R-10 model 2 (Trimble, USA). Data $\mathrm{z}$ měření byla zpracovaná standardním postupem $\mathrm{v}$ programu LEAD2. Mapa změny magnetické intenzity magnetického pole (magnetogram) v jednotkách nanoTesla (nT) byla následně vyhlazena průměrováním. Pro účely prezentace a interpretace výsledků byl použit software ArcGIS Desktop 10.7 (ESRI).

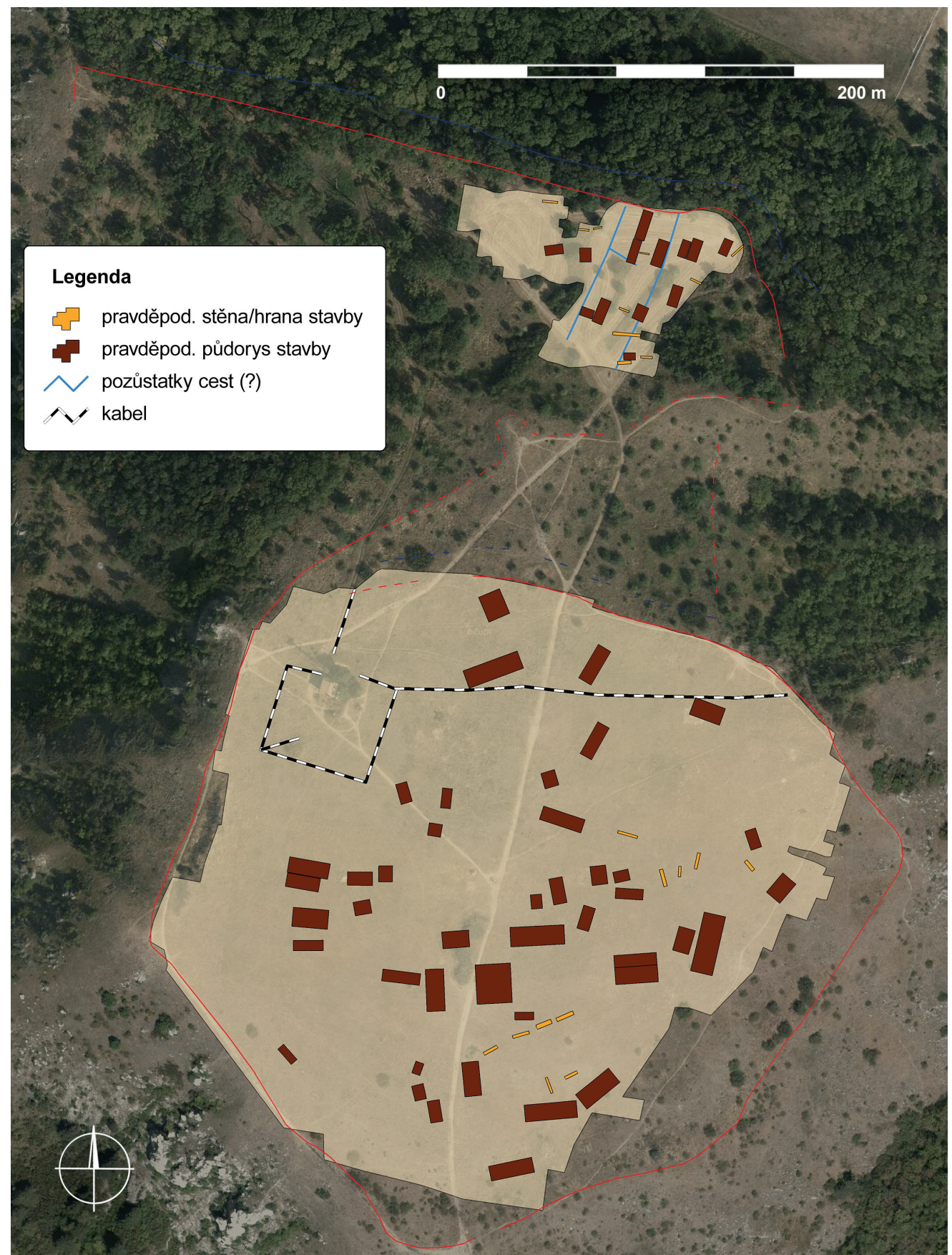

Obr. 9. Interpretace výsledků geomagnetické prospekce. Podkladová data Český úřad zeměměřický a katastrální. Autor T. Tencer.

Fig. 9. Interpretaiton of the geomagnetic survey results. Background data by State Administration of Land Surveying and Cadastre. Author T. Tencer. 
Geomagnetický průzkum polohy se uskutečnil v únoru 2020. Celkově prozkoumaná plocha činila 6,6 ha (akropole - 6,1 ha; předhradí - 0,5 ha). Prospekce měla za úkol identifikovat potenciální archeologické objekty na zkoumaném území, především však struktury, které by mohly indikovat osídlení. V době průzkumu byla zkoumaná plocha pokryta nízkou vegetací. Povrch byl rovný a tvrdý. Na ploše a v jejím bezprostř̌edním okolí se nacházelo několik recentních magnetických struktur - ploty, budova vysílače, stabilní bod jednotné trigonometrické sítě apod.

Geologické podloží zkoumaných ploch je tvořeno kamenitými až hlinito-kamenitými sedimenty. Mocnost půdního horizontu dosahuje mnohdy pouhých $20 \mathrm{~cm}$ a na mnoha místech vystupuje kamenné vápenité podloží prrímo na povrch. I přes tyto nepř́ínivé geologické podmínky můžeme konstatovat, že podloží poskytlo dostatečný kontrast k zachycení archeologických struktur.

Geomagnetická prospekce odhalila množství magnetických anomálií (obr. 8, 9). Jejich interpretace však není jednoduchá. Vzhledem k tenké vrstvě nadloží nelze očekávat výrazněji zahloubené objekty. Na ploše jsme nezachytili anomálie indikující typické sídlištní jámy, i když jejich přítomnost nelze vyloučit. Jako archeologicky relevantní anomálie jsme identifikovali především podlouhlé anomálie s amplitudou magnetických hodnot kolem 15-20 nT. Tyto anomálie mnohdy tvoří skupinky paralelních nebo na sebe navzájem kolmých linií, které mají mnohdy nejednotný tvar a rozměry. Tyto skupiny lze interpretovat jako půdorysy nadzemních staveb. Půdorysy staveb byly zjištěny již v roce 2012 (Peška, Vránová eds. 2016, 26-27). Geomagnetickou prospekcí se podařilo tyto struktury identifikovat na akropoli a nově i na zkoumané části tzv. 2. předhradí.

Výše uvedené struktury jsme na akropoli zachytili hlavně v jižní části zkoumané plochy. Severní část je značně kontaminována recentní aktivitou, což lze především pozorovat na severovýchodě, kde vystupuje kamenné podloží až na povrch. Celkem bylo identifikováno a interpretováno 43 možných půdorysů staveb. Zachycená délka půdorysů je poměrně variabilní ( 5 až $25 \mathrm{~m}$ ). Naproti tomu šířka se pohybuje mezi 5-8 m. Jak bylo uvedeno výše, struktury jsou většinou tvořeny podlouhlými anomáliemi, v některých př́padech můžeme pozorovat dvě paralelní či na sebe kolmé linie nebo anomálii tvaru „U“. Identifikovány však byly i osamocené podlouhlé anomálie. Orientace staveb na akropoli není jednotná, lze zde však pozorovat určité lokální trendy, resp. koncentrace stejně orientovaných struktur. Vzájemná orientace některých staveb naznačuje možnou existenci dvorců. Půdorysy staveb identifikované na předhradí jsou až na výjimky orientované kratší stranou na osu sever-jih. Jejich vymezení je oproti strukturám na akropoli jednodušší. Zachycená délka je rovněž variabilní (6-13 m). Šířka se opět pohybuje kolem $5 \mathrm{~m}$. Kromě osamocených podlouhlých anomálií jsme na předhradí zachytili dvojici linií. Jedná se o lineární slabě magnetické anomálie. Jsou paralelní s delší osou staveb a navzájem se respektují. Mohlo by se jednat o pozůstatky cest, vzhledem $\mathrm{k}$ omezenému rozsahu jejich zachycení je ale jejich interpretace problematická.

Výrazné bipolární anomálie detekované především na akropoli lze spojit s rušivými vlivy recentních objektů (stavby vysílače, geodetické body, podzemní inženýrské sítě apod.). Rušivý vliv těchto struktur znemožnil detekci archeologických struktur v jejich okolí. Na akropoli a ani na předhradí jsme neidentifikovali skupiny či osamocené anomálie, které by šlo interpretovat jako výrobní okrsky, resp. pyrotechnologické objekty (pece).

Z výsledků geomagnetického průzkumu lze usuzovat, že akropole a zkoumaná část předhradí byly v minulosti osídleny. Na obou plochách byly zachyceny tvarově obdobné struktury. Jejich vzájemné uspořádání indikuje jistý stupeň organizované zástavby. Pochopitelně přesnější chronologické zařazení těchto struktur není samo o sobě bez dalšího archeologického výzkumu možné. Režim chráněné krajinné oblasti, které je Stolová hora součástí, však v současné době žádné terénní zásahy neumožňuje. Vzhledem k analogickému tvaru struktur je možné alespoň předpokládat jejich stejné chronologické zařazení. Situace navíc odpovídá zjištěním J. Říhovského, který během výzkumu v roce 1952 odkryl pozůstatky tří staveb dvou typů konstrukce kůlové a s kamennou podezdívkou (Ř́hovský 1955, 30).

Nutno zdůraznit, že geomagnetický průzkum zaznamenal především ty anomálie, které byly tvarově výrazné, a jednalo se o typické objekty větších rozměrů. Není vyloučeno, že se na ploše nacházejí jiné, menší objekty nebo objekty s méně výraznými výplněmi. Geomagnetickou prospekcí se tyto objekty nepodařilo zachytit. Lze předpokládat, že takové objekty se budou vyskytovat především v blízkosti identifikovaných objektů větších rozměrů, anebo $v$ těch místech, kde byla jejich přítomnost zastíněna recentním rušením. Celkový počet archeologických objektů zachycených na zkoumané ploše tak může být ve skutečnosti větší.

\section{Diskuse}

\section{Datace jednotlivých částí hradiště}

Problémem informací pocházejících z terénní a digitální prospekce reliktů opevnění a z magnetometrického měření je, že nám samy o sobě neř́ikají nic o jejich časovém zařazení. Data je proto třeba zapojit do kontextu dostupných informací získaných během výzkumů v 50. letech. Velkým prŕnosem v tomto ohledu jsou nálezy získané pomocí detektorové prospekce $\mathrm{v}$ letech 2008-2019.

Klíčovou akcí pro dataci Tabulové hory byl výzkum v roce 1952. J. Říhovský otevřel v místě předpokládané brány v reliktu valu na jižním okraji akropole sondu (obr. 4, 6). Na základě terénního pozorování rozeznává dvě stavební fáze valu. V první fázi mělo jít pouze o palisádové ohrazení. Druhá fáze valu vznikla dodatečnou přístavbou zadní palisádové plenty a nasypáním tělesa. Z hlediska datace dává Ř́hovský první fázi valu (respektive palisády) do souvislosti s nálezem pinzety mohylového charakteru ( Ŕíhovský 1955, 31). Samotnou pinzetu ani žádné bližší informace o ní se bohužel nepodařilo dohledat. Druhou fázi valu spojoval Ř́ihovský s vrcholným obdobím existence opevněné osady, které na základě keramických nálezů řadil do stupňů BrD - HaA ( ̌́íhovský 1955, 32). Během výzkumu byla nalezena také keramika a další předměty datovatelné do eneolitu a starší doby bronzové, kvantitativně však ve zcela marginálním množství. V roce 2018 byla provedena revize materiálu z výzkumů na akropoli z let 1952 a 1958 uloženého v Moravském zemském muzeu. Bylo zdokumentováno 305 signifikantních zlomků keramiky (okraje, dna, zlomky s výzdobou, výdutě s identifikovatelným profilem). Z nich je možno zařadit do eneolitu pouze 8 kusů (2,6 \%) a do starší doby bronzové 13 kusů (4,3\%). Veškerý ostatní střepový materiál je možné obecně datovat do období popelnicových polí s částečným možným přesahem do závěru mohylového období (93,1%). Tento obraz odpovídá Ríhovského závěrům o těžišti osídlení v době popelnicových polí.

Z akropole pochází řada již publikovaných chronologicky relevantních předmětů nalezených bud' náhodně v dávnější minulosti, nebo v průběhu výše zmíněných výzkumů. Mezi nimi je nejnápadnější soubor šesti jehlic. Dvě z nich se zduřelým krčkem (obr. 10: 1-2; Ř́íhovský 1979, č. 373, 415) spadají k typu Deinsdorf, a tedy do přechodného mohylovo-velatického horizontu až středních popelnicových polí (Říhovský 1979, 83, 85). Další dvě patří k typu jehlic s dvojkónickou schodovitě členěnou hlavicí 


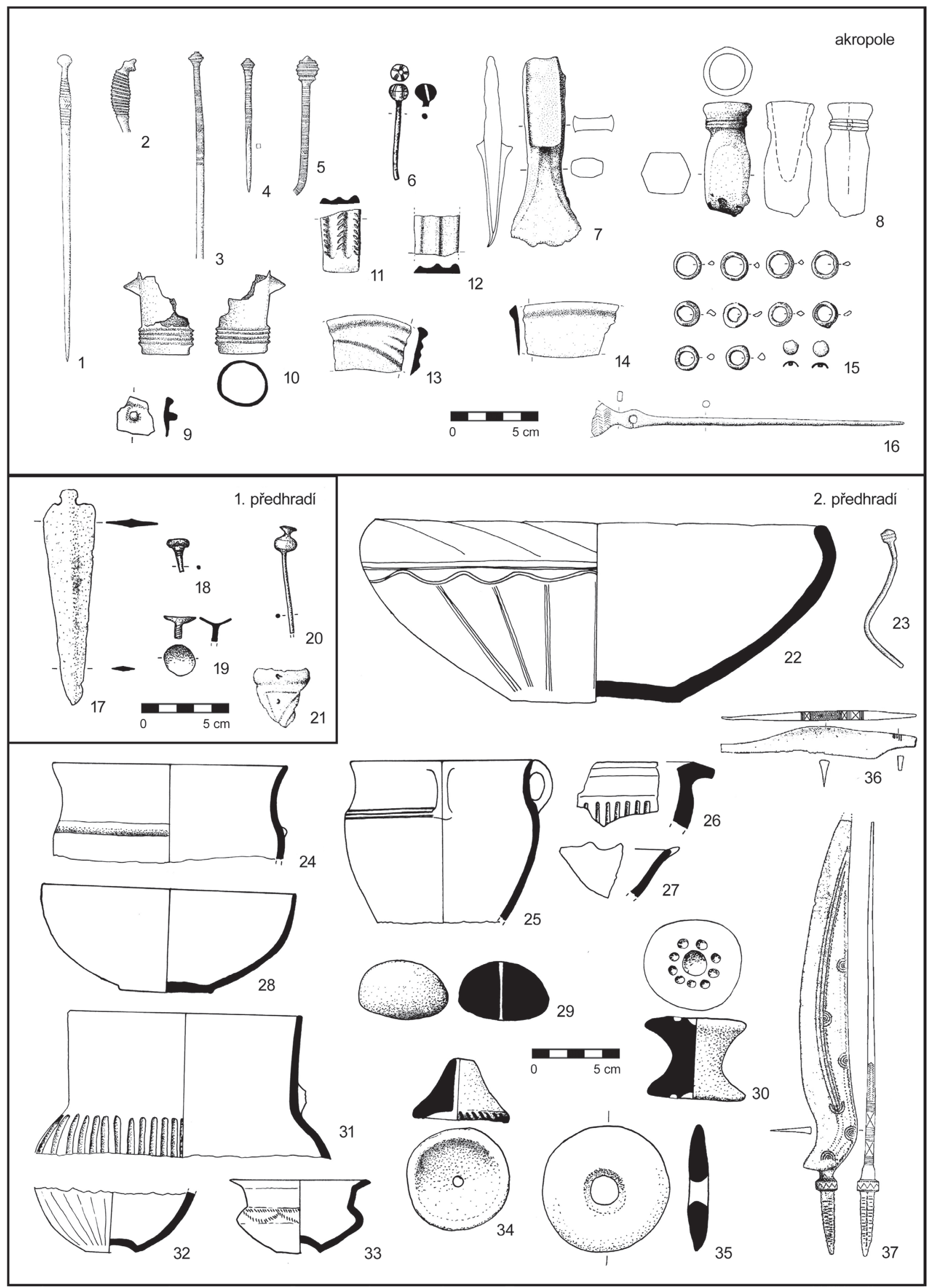

Obr. 10. výběr nálezů z Tabulové hory. Kresba A. Navrátil; podle Říhovský 1972; 1979; 1989.

Fig. 10. Selection of finds from Tabulová hora. Drawing by A. Navrátil; according to Říhovský 1972; 1979; 1989. 
(obr. 10: 3-4; Říhovský 1979, č. 734, 735), které se vyskytují průběžně od počátku popelnicových polí až k jejich konci (Ř́hovský 1979, 123-124). Rytím zdobená jehlice s vodorovně členěnou hlavicí, kterou J. Ríhovský řadí mezi jehlice s uzlíkem pod krčkem (obr. 10: 5; Říhovský 1979, č. 1281) by měla být typickým zástupcem středního a přechodného stupně popelnicových polí (Říhovský 1979, 165). Poslední jehlicí je doposud nepublikovaný exemplář jehlice s kulovitou šikmo proděravělou hlavicí, která pochází z výzkumu z roku 1952 a je typickým zástupcem stupně BrA2, respektive BrB1 (obr. 10: 6; Stuchlík 2006, 179). Chronologicky signifikantní je do jisté míry také depot několika stovek kroužků Klentnice 2, nebot masový výskyt kroužků v depotech je typický pro období mladších popelnicových polí (Navrátil 2008; Salaš 2005, 103). Do starších až středních popelnicových polí je možné datovat dva předměty nordické provenience kladívko, nalezené u detektorářského vkopu v roce 2008 (Navrátil 2008; Salaš 2014, 69-70), a sekerku se schůdkem, nalezenou při budování vysílače v roce 1970 (obr. 10: 7; Říhovský 1992, 50, č. 321). Na kontakty s nordickou oblastí odkazuje ještě třetí předmět nalezený v prostoru vstupní šíje akropole jako nejspíše již jednou vyzvednutý a odhozený nález. Je jím torzo dvojramenného mlatu se čtyřmi plastickými žebry na tuleji a dvěma plastickými trny po stranách (obr. 10: 10). Provedení žeber nás směřuje $\mathrm{k}$ neobvyklému typu mlatů s ohlasy nordické provenience, jaké známe z depotu z Hulína, Velkého Blhu, případně z ojedinělého nálezu z Bratislavy (Novotná 1970, taf. 23: 391, taf. 24: 402; Novotná, Furman 2018, 85-86; Stuchlík 1988, obr. 18-19). Alternativně se může jednat o pozůstatek sekeromlatu s kotoučovitým týlem, který má analogii v unikátním sekeromlatu z depotu Velký Blh (Novotná 1970, taf. 22: 380). Na základě datace depotu Velký Blh do horizontu Forró, respektive Ópályi je tento typ mlatů/sekeromlatů datován do stupňů BrC2-BrD (Novotná, Furman 2018, 87-88).

Z 1. předhradí jsou doposud známé pouze nálezy z detektorové prospekce z let 2008-2019. Mezi výrazné a poměrně dobře datovatelné artefakty z této polohy patří čepel dýky s oválným týlem a dvěma otvory pro nýt (obr. 10: 17). Obecně platí, že tento typ dýk řadíme do staršího mohylového stupně (Vladár 1974, 13). Dále z této trati pocházejí tř̌i jehlice. První z nich je hrubě provedená tzv. jižní varianta jehlice s pečetítkovitou hlavicí (obr. 10: 18), která se nejčastěji vyskytuje v závěru mohylového období a ve starší fázi popelnicových polí (Ř́hovský 1979, 50-51). Druhá je jehlice s vázičkovitou hlavicí (obr. 10: 20), které se vyskytují od přechodného stupně starších a mladších popelnicových polí do stupně HaB2 (Ř́hovský 1979, 2014-205). Třetí jehlicí je exemplář s číškovitou hlavicí (obr. 10: 19). Tento typ se objevuje od středního stupně popelnicových polí a přežívá do stupně Klentnice II, tedy HaB1 (Ř́hovský 1979, 212). Do popelnicových polí je také možno datovat zlomek sekerky s tulejkou zdobenou zavěšenými žebírky tvaru V (obr. 10: 21; Navrátil 2008).

Ze starších dobře datovatelných nálezů pochází z 2. předhradí dva bronzové nože. První byl nalezen náhodně v roce 1935 a jedná se o nůž s trnem typu Wien-Leopoldsberg, který je datovatelný do stupně Klentnice II a tedy Reineckeho stupně HaB1 (obr. 10: 37; Říhovský 1972, 69). Druhým exemplářem je nůž s plochým trnem typu Stillfried (obr. 10: 36), jehož nejčastější výskyt spadá do závěru starších a na počátek mladších popelnicových polí ( ̌́íhovský 1972, 58). Opomenout nelze depot Klentnice 1 datovaný do stupně HaB1 (Salaš 2005, 427). Z této polohy pochází také několik keramických nálezů, objevených J. Říhovským v roce 1957 během povrchového sběru v prostoru odbagrovaných svahů fotbalového hřiště, které je možné datovat do období popelnicových polí (obr. 10: 22, 24-35; nálezová zpráva
Archeologického ústavu, Brno č. j. 772/60). Z detektorových prospekcí pochází nález jehlice $\mathrm{s}$ vř̌etenovitou hlavicí varianta Klentnice, která se vyskytuje od závěru střední doby bronzové do mladší fáze popelnicových polí (obr. 10: 23; Říhovský 1972, 179-181). Název varianty odráží fakt, že z katastru Klentnice pochází 20 těchto jehlic (většina z žárového pohřebiště - Říhovský 1972, 176-178).

Blíže nelokalizován a bohužel také neověritelný je nález souboru zlatých vlasových ozdob ze starší doby bronzové, který údajně také pochází z Tabulové hory (Stuchlík 2018).

Celkově shrnuto, až na několik jednotlivých předmětů z eneolitu a starší doby bronzové nalezených na akropoli a na jednu mohylovou dýku z 1. předhradí, je možné drtivou většinu chronologicky signifikantních nálezů ze všech ploch hradiska datovat do popelnicových polí v rozpětí od mohylovo-velatického stupně po mladší popelnicová pole. Tento fakt spolu s typovým charakterem lokality a datací valu akropole nás opravňuje $\mathrm{k}$ domněnce, že nejen akropoli, ale i existenci 1. a 2. předhradí včetně opevnění je možné datovat do období popelnicových polí. Tomu nasvědčuje také skutečnost, že bez návaznosti na akropoli by opevnění obou předhradí nemělo valného smyslu. Nejintenzivnější aktivitu v době popelnicových polí potvrzují také archeologické nálezy z okolí Tabulové hory, kterými jsou rozsáhlá sít satelitních sídlišt a pohřebiště $s$ největším počtem datovatelných hrobů ve stupni Klentnice I - tedy HaA/HaB (Ř́hovský 1965a; 1965b).

Na úvahy o dataci lokality lze navázat polemiku k dataci potencionálních stavebních struktur zjištěných magnetometrickým měřením. Doklady osídlení mladšího, než je doba popelnicových polí, na Tabulové hoře zcela chybí a doklady starších aktivit jsou jen velmi sporadické. Ačkoliv lokalita byla v průběhu eneolitu a starší i střední doby bronzové zjevně nějakým způsobem využívána, přesvědčivé doklady trvalého sídelního využití pocházejí zatím pouze z období popelnicových polí. Na to poukazuje i datace valu a s ním chronologicky související pozůstatky zjištěných staveb ( ̌́íhovský 1955, 30). Pozůstatky struktur odhalené magnetometrem je proto s největší pravděpodobností možné řadit právě do tohoto období.

\section{Konstrukce hradby}

Obsáhlá nálezová zpráva z výzkumu valu v roce 1952 je bohužel v současné době nezvěstná. Z popisu a kresby v Archeologických rozhledech č. 7 je objektivní situace v terénu jen obtížně rekonstruovatelná. První fázi opevnění měla tvořit pouze palisáda, zatímco v druhé fázi byla k palisádě doplněna zadní plenta a prostor mezi ní a palisádou byl vyplněn náspem. K zadní plentě pak byla přisypána rampa. Mimo existenci valu potvrdil výzkum také přítomnost př́íkopu a brány. Př́íkop o šírce až $220 \mathrm{~cm}$ a hloubce 40-50 cm byl vysekán do skály a v místě vstupu do ohrazení přerušen. $\mathrm{V}$ odkryté části příkopu byly zdokumentovány dvě neúplné lidské kostry, jejichž dochované části byly stále v anatomické poloze (Říhovský 1955, 30-31).

Na základě studia fotografií výzkumu uložených v archivu Archeologického ústavu Akademie věd v Brně se zdá, že cca $2 \mathrm{~m}$ široký val mohl mít vnější plentu tvořenu z velkých vápencových kamenů (obr. 4: 1). O té se však J. Říhovský nezmiňuje, a naopak na základě zjištěných kůlových jam vytesaných ve skále uvažuje o plentě dřevěné. Je tedy otázkou, zda je poloha kamenů na řezu náhodná, nebo došlo ke špatné interpretaci situace. Jiná fotografie téže sondy naznačuje, že velké kameny byly v místě plenty i na protějším profilu (Čižmář 2004, 145). Je tedy možné skutečně uvažovat o nerozpoznané kamenné plentě, která byla nejspíše zpevněná kůlovou konstrukcí. Za plentou pokračuje těleso valu tvořené náspem z menších kamenů a zeminy (obr. 4: 2). 
Na fotografiích je také patrná zmiňovaná rampa (obr. 4: 4-5), jejíž výplň má viditelně odlišný charakter od výplně valu (méně kamenů, více zeminy), zatímco povrch rampy je „dlážděn“ většími vápencovými kameny.

\section{Společenská role Tabulové hory v době popelnicových polí}

Významu hradišt z doby bronzové a jejich opevnění byla v domácíliteratuře věnována řada studií. V těchto pracích byla hradištím přisuzována vesměs primárně obranná a ekonomicko-sociální funkce. Skloňovány jsou také role hradišt coby center specializovaných řemesel, obchodu, rituálních praktik či nástrojů prezentace moci (Čižmář 2004, 52; Čtverák et al. 2003, 8, 16; Dohnal 1988, 2-21; Furmánek, Vladár 1983, 9; Hrubý, Chvojka 2002, 611; Salaš 1987, 282; Stuchlíková 1987, 396; Šaldová 1977, 138, 156; Vencl 1983). Obecným problémem těchto prací je skutečnost, že úvahy o roli hradišť zde vycházejí pouze z induktivnı́ interpretace archeologických pramenů bez jakéhokoliv teoretického zázemí, které by pracovalo s nějakým společenským modelem doby bronzové. Argumenty se nejčastěji opírají o empirický pragmatismus a kulturně-historické představy o neustálých kmenových pohybech. Zpravidla bývá zcela opomíjena ideologická a symbolická rovina celé problematiky. K úspěšné rekonstrukci živého světa pravěkých společností však samotné archeologické nálezy nestačí. Na základě archeologických pramenů a většinou s pomocí jiných vědních oborů můžeme pouze sestavovat modely, jejichž platnost je nutné dále testovat (Neustupný 2007, 46-48, 181). Mimo archeologická data musí takový model reflektovat antropologické poznatky o fungování archaických společností, stejně jako relevantní ikonografické a literární památky, pokud jsou k dispozici. Během posledních desetiletí vyšla v anglofonním prostřredí řada studií, které s podobnými modely různých aspektů života $\mathrm{v}$ době bronzové pracují (Earle et al. 2015; Earle, Kristiansen eds. 2010; Fokkens, Harding 2013; Harding 2000; Horn, Kristiansen 2013; 2018; Kristiansen, Larsson 2005; Vandkilde et al. 2015).

Řada studií byla věnována také modelu toho aspektu doby bronzové, který úzce souvisí s problematikou hradišt a jejich opevněním - fenoménu válečnictví (Horn, Kristiansen 2018; Kristiansen 1999; Treherne 1995; Vandkilde 2006). Samotná existence opevnění nenechávala mnoho badatelů na pochybách, že hlavním smyslem opevněných hradišt byla obrana. Bipolární vývoj názorů na otázku, zda mělo pravěké opevnění praktickou, či spíše symbolickou funkci, byl v anglofonním prostř̌edí dlouho diskutovaným tématem, spojeným mimo jiné s vývojem procesuálního a post-procesuálního paradigmatu (Armit 2007, 29-30). V našich zeměpisných šírkách se tento názorový spor odrazil jen okrajově, nejmarkantněji v diskusi k pravěkému ohrazení v Klech (Gojda et al. 2002; Kuna 2002; Vencl 2002; k tomu také Neustupný 2010, 86-88). Navzdory této diskusi je zřejmé, že defenzivní (respektive praktický) účel opevnění byl a nejspíše stále i je hlavním domácím názorovým proudem (srov. Bartík 2015, 24-25, 30; Dohnal 1988, 11, 20-21; Furmánek et al. 2015, 108, 256; Šaldová 1977, 138; Vencl 1983, 288-289; Vencl 2002, 431).

Cílem této práce není snižovat defenzivní význam opevnění hradišť. Je však třeba jej zasadit do výše zmíněného modelu válečnictví doby bronzové. $\mathrm{V}$ tomto modelu je válečnictví do jisté míry ritualizováno a formalizováno. Je důležitým prvkem mužské identity a nedílnou součástí myšlenkového světa doby bronzové (Armit 2007, 33; Armit 2011, 12; Harding 2000, 307; srov. Ling, Toreld 2018, fig. 5.2). V tomto období již musíme počítat s ojedinělými konflikty velkého rozsahu (Jantzen et al. eds. 2014), základním modelem však stále byly válečnické družiny v počtu desítek nebo nižších stovek bojovníků (Harding 2006, 108; Kristiansen 2018, 26-27). Z hlediska opevnění je důležité, že na této úrovni společenského vývoje nelze kalkulovat s vojenskou morálkou charakteristickou pro státní aparát s organizovanou vojenskou složkou, která by akceptovala ztráty nezbytné pro př́mý útok na opevněné a dobře hájené pozice (Armit 2007, 28). Pokud byly valy účinně hájené, je třeba počítat s tím, že v kontextu válečnictví doby bronzové byly prakticky nepřekonatelnou překážkou. Jako ilustrace v tomto ohledu poslouží Homérova Iliada, kde se při obléhání Tróje omezují bojové aktivity účastníků na formální střety před branou, na loupeživé výpady do okolí nebo na záškodnické akce jednotlivců ( $\mathrm{k}$ relevanci homérských eposů viz Sherratt 1990). Je také třeba zmínit, že konkrétně na Tabulové hoře měří délka př́stupného opevnění cca $1200 \mathrm{~m}$, což by pro efektivní obranu vyžadovalo obránce $\mathrm{v}$ počtu mnoha stovek.

Pokud se zabýváme významem opevnění, nemůžeme opomenout jeho symbolickou a ideologickou roli, která byla v očích tehdejší společnosti minimálně stejně důležitá jako ta praktická. Hlavním aspektem této role bylo nejen vymezení geografického prostoru, ale především vydělení prostoru ve společenské identitě pro ty, kteří jsou uvnitř, a ty, kteří jsou vně (Harding 2006, 97). Nelze také opomenout vztah opevnění k okolní krajině. Vztyčení valu, stejně jako např́ílad mohyly, bylo svého druhu nepřehlédnutelným „zápisem“ do sociální krajiny (Harding 2006, 97; Neustupný 2010,149$)$. Tento zápis obsahoval pro tehdejšího pozorovatele řadu sdělení.

Nápadná je také monumentalita hradiště Tabulová hora a dalších hradišt na podobných místech, kde jsou dominantní postavení v krajině, př́tomnost výrazných geomorfologických prvků a rozloha upřednostněny před strategicky výhodnějšími polohami (tzv. hradiště typu Plešivec podle Čtverák et al. 2003, 13; na Moravě jsou to např. Olbramovice - Leskoun, Buchlovice - Holý kopec, Štramberk - Kotouč). Tou je v př́padě soutoku Dyje, Svratky a Jihlavy jednoznačně poloha Mušov - Burgstall, která umožňovala mnohem aktivnější kontrolu nad okolní krajinou, jak potvrzuje přítomnost římské vojenské stanice. Na nepraktičnost sídlení na Tabulové hoře ukazuje také fakt, že po zániku hradiště v pozdní době bronzové nebyla Tabulová hora k trvalým sídelním účelům již nikdy využita (a pravděpodobně ani před tím). Dalším charakteristickým prvkem tohoto druhu lokalit je nápadná koncentrace bronzových depotů. O těch z Tabulové hory víme většinou bohužel jen zprostř̌edkovaně (Navrátil 2010). Důraz na monumentalitu a rituální aspekt zcela zapadá do antropologického obrazu náčelnictví, podle kterého byly monumenty, ohrazení a ceremoniální místa důležitým prvkem elit v budování jejich prestižního „božského“ statutu ve společnosti i v krajině (Earle 1987, 299, srov. Jaeger, Czebreszuk 2010, 225).

Tímto se dostáváme k dalšímu společenskému aspektu doby bronzové, který úzce souvisí s válečnictvím i hradišti - společenské stratifikaci a vzniku elit. V pohřebním ritu doby bronzové je odraz vertikální společenské stratifikace a jejího napojení na válečnické a mužské atributy zřejmý (Anderson 2018; Harding 2015; Kristiansen 1999; Kytlicová 1988; Treherne 1995; Vandkilde 2018; srov. Havlíková, Krištuf 2017; Říhovský 1956). Propojení elit s existencí hradišt je však optikou archeologických pramenů problematické. Nedostatek archeologických dokladů př́tomnosti elit na hradištích doby popelnicových polí vedl čelní protagonisty teoretických úvah o funkci hradišt V. Šaldovou a V. Dohnala k závěru, že hradiště byla agrárními sídly rodového typu bez známek větší společenské stratifikace (Dohnal 1988, 20; Šaldová 1977, 156; srov. Bartík 2015, 30; Parma a kol. 2017, 355-362). K tomu je nutno dodat, že dokládání př́tomnosti elit v sídlištním kontextu standardními archeologickými metodami je problematické např́č celým pravěkým a raně historickým obdobím. Teprve s nástupem masivního užívání detektorů kovů se tato situace začala 
dramaticky měnit, a na světlo světa vyšlo už mnoho unikátních předmětů z lokalit, které byly dříve považovány za běžná sídliště, nebo nebyly známy vůbec (Navrátil 2015; srov. Parma a kol. 2017, 360). To platí také o hradiscích doby bronzové (např. Čižmář, Salaš 2009; Vích 2012). Např́klad systematický výzkum na Tabulové hoře v 50. letech nepřinesl žádné doklady metalurgie či dálkových kontaktů. Výše zmíněné předměty nordické provenience byly až na jednu výjimku objeveny po roce 2000 pomocí detektorů kovů, a bohužel vždy jako nežádoucí „odpad“ zanechaný na místě hledači pokladů. Během detektorové prospekce v letech 2008-2019 bylo na všech třech plochách hradiska nalezeno několik desítek kusů kovové suroviny a výrobního odpadu z odlévacího procesu (tyto nálezy budou podrobně popsány vjiné studii). Do tohoto kontextu zapadají i bohužel neověřitelné zprávy o nálezech exkluzivních zlatých předmětů datovatelných právě do doby popelnicových polí. Určitou míru kredibility těchto zpráv naznačuje podobný již zmiňovaný nález ze starší doby bronzové, který bylo naštěstí možno zdokumentovat (Stuchlík 2018).

\section{Závěr}

Hradiště Tabulová hora je z archeologického hlediska výjimečné v mnoha ohledech. Má exkluzivní polohu i geomorfologii a množství náhodně nalézaných artefaktů z doby bronzové přitahovalo badatelskou pozornost už počátkem 19. století. Oproti tomu systematický výzkum v 50. letech nepřinesl žádné zvláštní poznatky, které by exkluzivitu lokality nějakým způsobem potvrzovaly. Ke změně došlo až počátkem nového milénia, kdy se začaly $\mathrm{k}$ archeologům dostávat informace od amatérské veřejnosti, podle kterých se Stolová hora a okolí „těší“ nebývalé pozornosti rabovačů s detektory kovů. Z lokality měly být uloupeny desítky hromadných nálezů z doby bronzové, včetně exkluzivních předmětů ze zlata. Následné detektorové prospekce organizované mezi lety 2008-2019 skutečně potvrdily devastující charakter nelegálních zásahů. Přes míru narušení se podařilo najít extenzivní doklady metalurgie a také předměty poukazující na existenci dálkových kontaktů s nordickou oblastí. Dủležitým přínosem prospekcí v terénu bylo zjištění, že lokalita sestává nejen z náhorního plató, jak bylo ve starší literatuře uváděno, ale i ze dvou valem ohrazených předhradí. Celková rozloha lokality tak není původně uváděných 7,2, ale téměř 24 hektarů.

Na základě dostupného materiálu ze starších výzkumů a detektorových prospekcí je možné datovat těžiště existence všech tří opevněných částí hradiska obecně do doby popelnicových polí. Z akropole pocházejí také nálezy datovatelné do mohylovo-velatického horizontu.

$\mathrm{V}$ roce 2020 bylo přistoupeno $\mathrm{k}$ magnetometrickému měření většiny plochy akropole a části 1. předhradí. Navzdory nevhodným podmínkám, kde skalní podloží vystupuje místy jen několik málo centimetrů pod současný povrch, se podařilo zachytit anomálie, které naznačují existenci do určité míry organizované zástavby. Terénní výzkum za účelem ověření datace a charakteru struktur v současné chvíli není možný. Výzkumy z 50. let a celkový archeologický kontext však ukazují jako nejpravděpodobnější období existence hradiště mladší a pozdní dobu bronzovou.

$\mathrm{K}$ důležitým tématům týkajícím se fenoménu hradišt patří úvahy o jejich roli ve společnosti doby popelnicových polí. Domníváme se, že obecná absence dokladů přítomnosti elit na těchto hradištích není odrazem minulé reality, nýbrž odrazem extrémně omezených možností standardních výzkumů tyto doklady zachytit. Naopak se domníváme, že provázanost fenoménu hradiš̌̉ a společenské stratifikace velmi dobře zapadá do modelu strategie elit v budování jejich společenského postavení. V tomto modelu hraje klíčovou roli obchod (respektive směna) s bronzem, který se nejpozději v mohylovém období stal kulturní normou a společnosti se tak staly na bronzu závislé (Ling et al. 2017, 215; Neustupný 2010, 166-167; Pare 2000). Integrace bronzu v každodenním životě spolu se specializací nezbytnou k jeho těžbě, zpracování, dopravě na dlouhé vzdálenosti a k výrobě finálních předmětů vedly k nerovnému př́stupu ke zdrojům (Earle et al. 2015). Výsledkem byla rozvíjející se sociální stratifikace doprovázená vznikem lokálních společenských a válečnických elit, které si kontrolou nad alespoň některým z výše zmíněných aspektů obchodu s bronzem zajištovaly své postavení. Na dálkových trasách vznikaly elitami kontrolované komunikační uzly, které byly zároveň průchozími body prestižního zboží, nových technologií, ideologií a inovací (srov. Earle 1989, 86; Vandkilde 2014, 605). Důležitým aspektem tohoto modelu je také premisa odvozená z antropologické zkušenosti, že moc elit v náčelnických společnostech se neopírala pouze o ekonomické, ale také o ideologické a symbolické aspekty svého působení, které jejich postavení legitimizovalo v očích společnosti (Earle 1997, 143).

Všechny výrazné prvky Tabulové hory do výše popsaného modelu dobře zapadají. Patří k nim exkluzivní poloha na předpokládaných dálkových trasách, které sledovaly komunikační koridory podél hlavních toků řek. Napojení na dálkové trasy naznačují nálezy předmětů nordické provenience. Metalurgickou činnost na lokalitě dokládají početné nálezy suroviny a odpadního materiálu z odlévacího procesu. Dalším prvkem charakteristickým pro Tabulovou horu je její monumentalita. Dominantní postavení v krajině, prrítomnost výrazných geomorfologických prvků, opevněná plocha dosahující téměř 24 ha, délka opevnění přesahující $2 \mathrm{~km}$ a zároveň značná nepraktičnost jak z hlediska sídlení, tak z hlediska militaristického zřetelně naznačuje, že symbolické a ideologické aspekty byly pro stavitele důležitější, než aspekty praktické. Pokud budeme věřit informacím, které se týkají rabování lokality v posledních desetiletích, lze zde předpokládat i bohatou rituální činnost, kterou dokládají bronzové depoty, jakož i výskyt dalších exkluzivních předmětů.

Domníváme se proto, že Tabulová hora mohla v době svého rozkvětu působit jako centrální lokalita regionálního a pravděpodobně i nadregionálního významu. Její poloha umožňovala náčelnickým elitám kontrolu nad křižovatkou transportních tras v osách řek Dyje, Svratky a Jihlavy. Dominantní poloha v krajině s výraznými geomorfologickými prvky a monumentální rozloha opevnění měla především ideologický a symbolický význam v myšlenkovém světě tehdejší společnosti. Tento druh lokalit představoval jeden díl komplexní mozaiky společenského systému, ve kterém si elity udržovaly své mimořádné postavení.

\section{Poděkování}

Rádi bychom poděkovali všem, kteří přispěli ke vzniku tohoto článku, zejména Ondřeji Chvojkovi a Luboši Jiráňovi za podnětné připomínky. Díky patří Petru Kubínovi a Františku Trampotovi z Regionálního muzea v Mikulově za podporu a také Jiřímu Matuškovi z CHKO Pálava za vstřícnost při zajištování přístupu na lokalitu. Geomagnetický průzkum byl umožněn díky projektu aplikovaného výzkumu a vývoje národní a kulturní identity (NAKI II, Ministerstvo kultury ČR) č. DG18P02OVV058 s názvem „Archeologie z nebe. Analýza a prezentace fondů dálkového průzkumu na Moravě a ve Slezsku“. Díky patří také všem dobrovolným spolupracovníkům ze sdružení Archeo Moravia z.s., kteří nezištně a ve svém volném čase pomáhali s prospekcí. 


\section{Literatura}

Anderson, K. 2018: Becoming the Warrior. Constructed Identity or Functional Identity? In: Ch. Horn, K. Kristiansen (eds.): Warfare in Bronze Age Society. Cambridge: Cambridge University Press, 213-228.

Armit, I. 2007: Hillforts at War. From Maiden Castle to Taniwaha Pa. Proceedings of the Prehistoric Society 73, 22-38.

Armit, I. 2011: Violence and society in the deep human past. British Journal of Criminology [online] 51(3), 499-517. [cit. 2020-05-11]. DOI: $10.1093 / \mathrm{bjc} / \mathrm{azq} 076$. Dostupné z: https://doi.org/10.1093/bjc/azq076.

Bartík, J. 2015: Hradiská z mladšej a neskorej doby bronzovej v Malých Karpatoch. In: P. Jenčík, V. Struhár: Hradiská - svedkovia dávnych čias. Zborník odborných príspevkov o hradiskách a ich obyvatel’och. Dolná Mariková: Občianské združenie Hradiská.

Čižmář, M. 2004: Encyklopedie hradišt’ na Moravě a ve Slezsku. Praha: Libri.

Čižmář, M., Salaš, M. 2009: Nové hradiště v Moravské bráně. Archeologické rozhledy LXI(1), 63-76.

Čtverák, V., Lutovský, M., Slabina, M., Smejtek, L. 2003: Encyklopedie hradišt’ v Čechách. Praha: Libri.

Dohnal, V. 1988: Opevněná sídliště z doby popelnicových polí na Moravě. Studie muzea Kroměřížska 88. Kroměříž: Muzeum Kroměřížska.

Earle, T. 1987: Chiefdoms in Archeological and Ethnohistorical Perspective. Annual Review of Anthropology 16, 279-308.

Earle, T. 1989: The Evolution of Chiefdoms. Current Anthropology $30(1), 84-88$.

Earle, T. 1997: How Chiefs Come to Power. The Political Economy in Prehistory. Standford: Standford University Press.

Earle, T., Kristiansen, K. (eds.) 2010: Organizing Bronze Age Societies: The Mediterranean, Central Europe, and Scandanavia Compared. Cambridge: Cambridge University Press.

Earle, T., Ling, J., Uhnér, C., Stos-Gale, Z., Melheim, L. 2015: The Political Economy and Metal Trade in Bronze Age Europe. Understanding Regional Variability in Terms of Comparative Advantages and Articulations. European Journal of Archaeology 18(4), 633-657.

Fokkens, H., Harding, A. F. 2013: The Oxford Handbook of the European Bronze Age. Oxford: Oxford University Press.

Furmánek, V., Bátora, J., Ožd'áni, O., Mitáš, V., Kujovský, R., Vladár, J. 2015: Staré Slovensko 4. Nitra: Archeologický ústav Slovenskej akadémie vied.

Furmánek, V., Vladár, J. 1983: Opevnené osady doby bronzovej na Slovensku. Archeologické rozhledy XXXV(1), 3-12.

Gojda, M., Dreslerová, D., Křivánek, M. 2002: Velké pravěké ohrazení v Klech (okr. Mělník). Využití nedestruktivních metod výzkumu k poznání nového typu areálu. Archeologické rozhledy $\operatorname{LIV}(2), 371-430$.

Gojda, M., John, J. (eds.) 2013: Archeologie a letecké laserové skenování krajiny. Plzeň: Západočeská univerzita v Plzni.

Goláňová, P., Navrátil, A. 2017: The Pálava Hills during the La Tène Period. In: J. Kysela, A. Danielisová, J. Militký (eds.): Stories that made the Iron Age. Studies in Iron Age Archaeology Dedicated to Natalie Venclová. Praha: Institute of Archaeology of the Czech Academy of Sciences, v. v. i.; Charles University, Faculty of Arts, 393-409.

Harding, A. F. 2000: European Societies in the Bronze Age. Cambridge: Cambridge University Press.

Harding, A. F. 2006: Enclosing and excluding in Bronze Age Europe. In: A. F. Harding, S. Sievers, N. Venclová (eds.): Enclosing the Past: inside and outside in prehistory. Sheffield: Collis, 97-115.

Harding, A. F. 2015: The Emergence of Elite Identities in Bronze Age Europe. Origini. Prehistory and Protohistory of Ancient Civilizations $\operatorname{XXXCII}(2), 111-121$.
Havlíková, M., Krištuf, P. 2017: Význam zbraní v pohřebním ritu střední doby bronzové. Archeologie ve středních Čechách 21(1), 261-271.

Horn, Ch., Kristiansen, K. 2018: Introducing Bronze Age Warfare. In: Ch. Horn, K. Kristiansen (eds.): Warfare in Bronze Age Society. Cambridge: Cambridge University Press, 1-15.

Hrubý, P., Chvojka, O. 2002: Výšinné lokality mladší a pozdní doby bronzové v jižních Čechách. Archeologické rozhledy LIV(3), 582-624.

Jaeger, M., Czebreszuk, J. 2010: Does a Periphery Look Like That? The Cultural Landscape of the Unetice Culture's Kościan Group. In: Kiel Graduate School „Human Development in Landscapes“ (ed.): Landscapes and Human Development: The Contribution of European Archaeology. Universtätsforschungen zur Prähistorischen Archäologie 191. Bonn: Rudolf Habelt, 217-235.

Jantzen, D., Orschiedt, J., Piek, J., Terberger, T. (eds.) 2014: Tod im Tollensetal. Forschungen zu den Hinterlassenschaften eines bronzezeitlichen Gewaltkonfliktes in Mecklenburg Vorpommern 1. Die Forschungen bis 2011. Schwerin: Landesamt für Kultur und Denkmalpflege Mecklenburg-Vorpommern.

Kirsch, O. 2008: Německé muzejnictví na Moravě [online]. Rkp. disertační práce. Masarykova univerzita. Filozofická fakulta. Historický ústav. Uloženo: Archiv závěrečných prací Filozofické fakulty Masarykovy univerzity. Dostupné z: https://is.muni.cz/th/j66ej/.

Klemm, G. 1836: Handbuch der germanischen Alterthumskunde. Dresden: Walthersche Hofbuchhandlung.

Koch, M. 1853: Bericht über Alterthümer im Nikolsburger Bezirk. Schriften der historisch-statistischen Section der k.k.m. schl. Gesellschaft des Ackerbaues, der Natur-und Landeskunde V, 25-29.

Kristiansen, K. 1999: The Emergence of Warrior Aristocracies in Later European Prehistory and Their Long-Term History. In: J. Carman, A. F. Harding (eds.): Ancient Warfare. Stroud: Sutton publishing, 175-189.

Kristiansen, K. 2013: Households in Context. Cosmology, Economy and Long-Term Change in the Bronze Age of Northern Europe. In: G. K. M. Madella, B. Kulcsarne-Berzsenyi, I. B. Godiano (eds.): The Archaeology of Household. Oxford: Oxbow Books, 235-268.

Kristiansen, K. 2018: Warfare and the Political Economy: Europe 1500-1100 BC. In: Ch. Horn, K. Kristiansen (eds.): Warfare in Bronze Age Society. Cambridge: Cambridge University Press, 23-46.

Kristiansen, K., Larsson, T. B. 2005: The Rise of Bronze Age Society. Cambridge University Press.

Kuna, M. 2002: O věcech praktických a nepraktických. Komentář k poznámkám S. Vencla. Archeologické rozhledy LIV(2), 436-438.

Kuna, M., Tomášek, M. 2004: Povrchový průzkum reliéfních tvarů. In: M. Kuna a kol.: Nedestruktivní archeologie. Praha: Academia, 237-296.

Kytlicová, O. 1988: K sociální struktuře kultury popelnicových polí. Památky archeologické LXXIX(2), 342-389.

Liedermann, J. 1873: Prähistorische Ansiedlungen im Nikolsburger Bezirk. Mitteilungen der Anthropologischen Gesellschaft in Wien III, 135-146.

Ling, J.,Cornell, P., Kristiansen, K. 2017: Bronze Economy and Mode of Production: The Role of Comparative Advantages in Temperate Europe during the Bronze Age. In: R. M. Rosenswig, J. J. Cunningham (eds.): In Modes of Production and Archaeology. Gainesville: University Press of Florida, 207-230.

Ling, J., Toreld, A. 2018: Maritime Warfare in Scandinavian Rock Art. In: Ch. Horn, K. Kristiansen (eds.): Warfare in Bronze Age Society. Cambridge: Cambridge University Press, 61-80.

Navrátil, A. 2008: Po stopách „hledačů pokladů“. Sborník Regionálního muzea v Mikulově RegioM 2008, 82-84.

Navrátil, A. 2010: Nové nálezy z „Tabulové hory“ u Klentnice a stav archeologické nevědomosti. Přehled výzkumů 51, 97-107. 
Navrátil, A. 2015: Česká archeologie a čtvrt století užívání detektorů kovů. Přehled výzkumů 56(1), 119-130.

Nekvasil, J. 1991: Diskusní poznámky k problematice moravských hradisek středodunajské i lužické kultury. Archeologické rozhledy XLIII(3), 455-468.

Neustupný, E. 2007: Metoda archeologie. Plzeň: Vydavatelství a nakladatelství Aleš Čeněk.

Neustupný, E. 2010: Teorie archeologie. Plzeň: Vydavatelství a nakladatelství Aleš Čeněk.

Novotná, M. 1970: Die Äxte und Beilein der Slowakei. Prähistorische Bronzefunde IX(3). München: C.H. Beck-Verlag München.

Novotná, M., Furman, M. 2018: Bronzový depot z Belej-Dulíc, okres Martin a dvojramenné čakany karpatskej proveniencie. Památky archeologické CIX, 75-96.

Páleníková, J. 1953: Popelnicové pohřebiště v Klentnici na Moravě. Archeologické rozhledy V(5), 602-604, 630, 706, 714, obr. 275.

Pare, C. 2000: Bronze and the Bronze Age. In: C. Pare (ed.): Metals Make the World Go Round: Supply and Circulation of Metals in Bronze Age Europe. Oxford: Oxbow Books, 1-38.

Parma, D. a kol. 2017: Archeologie střední a mladší doby bronzové na Vyškovsku. Interpretační potenciál plošných záchranných výzkumü. Brno: Ústav archeologické památkové péče.

Peška, J. 1997: Nové poznatky o hradiscích z doby popelnicových polí na Pavlovských vrších. Přehled výzkumů 1993-1994, 87-93.

Peška, J., Vránová, V. (eds.) 2016: Věda rýče promluvila. Archeologické centrum Olomouc 1995-2015, stř́ipky. Olomouc: Archeologické centrum Olomouc.

Ř́íhovský, J. 1950: Hromadný nález bronzů z Klentnice u Mikulova. Archeologické rozhledy II(3-4), 217-221, 287, 294.

Ř́íhovský, J. 1955: Opevněná osada na Tabulové hoře u Klentnice na Moravě. Archeologické rozhledy VII(1), 28-32, 44-45, 128-129, 135-136.

Ř́íhovský, J. 1956: K datování antenového meče s jazykovitou rukojetí. Památky archeologické XLVII, 262-286.

Ř́hovský, J. 1957: Opevněné osady lidu velatické kultury na Pavlovských vrších na jižní Moravě. Archeologické rozhledy IX(1), 110-112.

Ř́íhovský, J. 1958: Opevněná osada na Tabulové hoře u Klentnice. Přehled výzkumů 1958, 35.

Ř́íhovský, J. 1965a: Das Urnengräberfeld von Klentnice. Fontes Archaeologici Pragenses 8. Pragae: Museum nationale Pragae.

Ř́íhovský, J. 1965b: Průzkum sídelní oblasti lidu středodunajských popelnicových polí v Pavlovských vrších. Přehled výzkumů 1964, 39.

Ř́ihovský, J. 1970: Halštatské hroby na pohřebišti v Klentnici. In: B. Klíma (ed.): Sborník Josefu Poulíkovi k šedesátinám. Brno: Archeologický ústav ČSAV, Brno, 43-54.

Ř́hovský, J. 1972: Die Messer in Mähren und dem Ostalpengebiet. Prähistorische Bronzefunde VII(1), München: C.H. Beck-Verlag München.

Ř́íhovský, J. 1979: Die Nadeln in Mähren und im Ostalpengebiet. Prähistorische Bronzefunde XIII(5). München: C.H. Beck-Verlag München.

Ř́íhovský, J. 1989: Die Sicheln in Mähren. Prähistorische Bronzefunde XVIII(3). München: C. H. Beck-Verlag München.

Ř́íhovský, J. 1992: Die Äxte, Beile, Meissel und Hämmer in Mähren. Prähistorische Bronzefunde IX(17). Stuttgart: Franz Steiner Verlag Stuttgart.

Salaš, M. 1987: Zur Frage der jungbronzezeitlichen Höhensiedlungen in Südmähren. In: Die Urnenfelderkulturen Mitteleuropas. Symposium Libice 21. - 25. 10. 1985, Praha, 277-286.

Salaš, M. 2005: Bronzové depoty střední až pozdní doby bronzové na Moravě a ve Slezsku. Brno: Moravské zemské muzeum.

Salaš, M. 2014: Kovadlinky, kladívka a př́lby z doby popelnicových polí na Moravě na pozadí depotu z Brna-Řečkovic. Památky archeologické CV, 47-86.
Sherratt, S. H. 1990: Reading the texts': archaeology and the Homeric question. Antiquity 64(245), 804-824.

Stuchlík, S. 1988: Bronzové sekeromlaty na Moravě. Památky archeologické LXXIX(2), 269-328.

Stuchlík, S. 2006: Borotice - mohylové pohřebiště z doby bronzové. Spisy Archeologického ústavu AV ČR Brno 30. Brno: Archeologický ústav AV ČR, Brno.

Stuchlík, S. 2018: Nové typy zlatých vlasových ozdob z Moravy, In: J. Bátora, R. Kujovský, M. Ruttkay, J. Vladár (eds.): Anton Toč́k. Legenda slovenskej archeológie. Nitra: Archeologický ústav Slovenskej akadémie vied, 161-168.

Stuchlíková, J. 1987: Nové výzkumy sídlišť věteřovské skupiny na jižní Moravě. Archeologické rozhledy XXXIX(1), 10-17, 107-108.

Šaldová, V. 1977: Sociálně - ekonomické podmínky vzniku a funkce hradišt z pozdní doby bronzové v západních Čechách. Památky archeologické LXVIII(1), 117-163.

Treherne, P. 1995: The Warriro's Beauty: The Masculine Body and Self-Identity in Bronze-Age Europe. Journal of European Archaeology 3(1), 105-144.

Vandkilde, H. 2006: Archaeology and war. Presentations of warriors and peasants in archaeological interpretations. In: T. Otto, H. Thrane, H. Vandkilde (eds.): Warfare and Society. Archaeological and Social Anthropological Perspectives. Aarhus: Aarhus University Press, 57-75.

Vandkilde, H. 2014: Breakthrough of the Nordic Bronze Age. Transcultural Warriorhood and a Carpathian Crossroad in the Sixteenth Century BC. European Journal of Archaeology 17(4), 602-633.

Vandkilde, H. 2018: Body Aesthetics, Fraternity and Warfare in the Long European Bronze Age: Postscriptum. In: Ch. Horn, K. Kristiansen (eds.): Warfare in Bronze Age Society. Cambridge: Cambridge University Press, 229-243.

Vandkilde, H., Hansen, S., Kotsakis, K., Kristiansen, K., Müller, J., Sofaer, J., Sørensen, M. L. S. 2015: Cultural Mobility in Bronze Age Europe. In: P. Suchowska-Ducke, S. S. Reiter, H. Vandkilde (red.): Forgin Identities. The Mobility of Culture in Bronze Age Europe. Report from a Marie Curie Project 2009-2012 with Concluding Conference at Aarhus University, Moesgaard 2012, Volume 1. British Archaeological Reports B A R. International Series 2771. Oxford. British Archaeological Reports Publishing, 5-37.

Vencl, S. 1983: K problematice fortifikací v archeologii. Archeologické rozhledy XXXV(3), 284-315.

Vencl, S. 2002: Poznámky k interpretaci ohrazení v Klech, okr. Mělník. Archeologické rozhledy LIV(2), 431-436.

Vích, D. 2009: Konference Detektory kovů v archeologii III. Archeologické rozhledy LIX(1), 141-142.

Vích, D. 2012: Kladky - neznámé hradiště na severozápadní Moravě. Památky archeologické CIII, 233-272.

Vladár, J. 1974: Die Dolche in der Slowakei. Prähistorische Bronzefunde VI(3). München: C.H. Beck-Verlag München.

\section{Summary}

Tabulová hora hillfort plays exclusive role in archaeology in many aspects. It has prominent geographical location on confluence of three major Moravian rivers. Its geomorphology makes it visible form tens of kilometers distance in otherwise low landscape. Numerous chance finds in the area dated to the Bronze Age were attracting attention as soon as at the beginning of the $19^{\text {th }}$ century (Klemm 1836, 440-442). In 1950 a hoard consisting of number of sickles, arm rings and other items dated mostly into $\mathrm{HaB1}$ was found on a slope of the hillfort. Regular excavation in 1952 and 1958 didn't bring any finds that would testify for any kind of special status of the site (Fig. 4; Ríhovský 1955). In 1952 
there was a simultaneous rescue excavation running on nearby urnfield burial ground just few hundred meters from the hillfort ( ̌́íhovský 1965a). Situation changed at the beginning of the $21^{\text {st }}$ century when rumours about illegal metal-detector activities on the site started to occur. According to these rumours a significant number of Bronze Age metal hoards as well as exquisite items including gold were looted from the site (Navrátil 2010). This information provoked a new wave of professional interest. Since the Tabulová hora site has been part of the Pálava Protected Landscape Area, no destructive excavation could take place here. Between 2008 and 2019 nearly 20 one-day metal-detecting surveys were organized by Brno city museum and Regional museum in Mikulov. A high level of damage to the site done by looters was confirmed. The surveys yielded almost 300 Bronze Age dated metal artefacts and also confirmed previous ideas that the hillfort was surrounded by number of satellite settlements and that there were significant activities on neighbouring hills as well. Strong evidence of metal-working was found the detailed information on this issue will be part of another study. At this point there are 3 items that can be typologically connected with the Nordic area and are probably evidence of long distance contacts (Fig. 10: 7, 8, 10).

So far known archaeological material from the excavation and surveys brought evidence of sporadic use of the Tabulová hora site in the Late Neolithic, Early and Middle Bronze Age. Significant rise of the activities starts at the transition from $\mathrm{Tu}-$ mulus to Urnfield peaking in $\mathrm{HaA}$ and the beginning of $\mathrm{HaB}$.

In 2013 a survey of remains of the hillfort's defense system was conducted. It was discovered that previously considered area of the hillfort on the Stolová hora hill is only the main part of the fortress and that there are two another walled sections adjacent to each other. This fact brings the overall area of the hillfort from previously thought 7.2 ha to almost 24 ha.

In 2020 the Department of Archaeology and Museology of Masaryk University organized a geomagnetic survey of the site. Recorded anomalies discovered linear and rectangular structures that give a hint about possible building structures (Fig. 8, 9). Thought the anomalies cannot give out any dating by itself, the archaeological context points at the Urnfield period as the most probable time of existence. Remains of structure of three buildings dated to Urnfield period were also found during the excavation in 1952 ( Ŕíhovský 1955, 30).

Important part of the discussion on Bronze Age hillforts is asking questions about their role in Bronze Age societies. The questions cannot be answered solely on the archaeological evidence. A model has to be developed. We share the opinion that the often mentioned difficulties in finding clear evidence of the presence of elites on Urnfield-period hillforts is not the reflection of historical reality rather than the evidence is almost invisible for standard excavation methods. After the advent of metal-detecting devices it is more and more obvious that most of the artefacts were not left behind in typically well studied sunken features, but rather in often overlooked upper layers. In fact the connection between hillforts and elites fits well into the model of social stratification and elites' strategies to gain and build their social status. Most often presented model is based on the assumption that during the Bronze Age bronze became integrated in everyday life and thus the societies became dependent on its supplies (Ling et al. 2017, 215; Pare 2000). The specialization needed for mining and processing of the ores, long-distance transport, smelting and creating final products led to unequal access to the resources (Earle et al. 2015). This resulted in development of local chiefs trying to control at least some parts of this operation chain - typically the transport routes. Some of the hillforts - including Tabulová hora - were well situated to stand as control nodes on these routes ( $c f$. Earle 1989, 86; Vandkilde 2014, 605). However, their role was not just to stand as a control point but also to represent the social status of the controlling chief. That is why the monumentality of the site (e.g. geographical and geomorphological significance in the landscape, extremely large but also hard to defend area) was obviously given priority before military and settlement suitability. Evidence of metallurgy and contacts to the Nordic area support these assumptions. It is also supported by the rumours that many hoards and exquisite gold-plated items were looted from the site.

We therefore assume that in the time of its flourishing in the Urnfield period the Tabulová hora hillfort played important regional and probably even supra-regional role of a political, economic and ritual center. Its monumentality is a reflection of local chiefs' strategies to imprint their status into the landscape and society.

\section{Kontakty}

Aleš Navrátil

Muzeum města Brna

Špilberk 210/1

CZ-662 24 Brno

navratil@spilberk.cz

\section{Richard Bíško}

Ústav archeologické památkové péče Brno, v. v. i.

Kaloudova 1321/30

CZ-614 00 Brno

bisko@uapp.cz

\section{Tomáš Tencer}

Masarykova univerzita

Filozofická fakulta

Arna Nováka 1

CZ-602 00 Brno

tencer@mail.muni.cz 
